\title{
Investigation of Damage in and Around Kathmandu Valley Related to the 2015 Gorkha, Nepal Earthquake and Beyond
}

\author{
Tsuneo Ohsumi · Yoichi Mukai · Hideo Fujitani
}

Received: 16 February 2016/ Accepted: 26 April 2016/Published online: 9 May 2016

(C) The Author(s) 2016. This article is published with open access at Springerlink.com

\begin{abstract}
An earthquake with a magnitude of 7.8 $\left(M_{w}\right)$ occurred at 11:56 NST (local time) on 25 April 2015, in the central part of Nepal (Gorkha).We organized a damage survey team and dispatched it to the affected area for several periods following the earthquake (May 26 to June 3: first trip, June 17 to 24: second trip, August 16 to 21: third trip and October 27 to November 2: forth trip) to investigate the damage and collect data. We found traditional construction methods are stronger than imagined. Many traditional earthquake-resistance technologies exist in Nepal. The first and second surveys were to collect timely statistical information on the damage to brick and stone masonry buildings and to confirm the availability of data and their sources for subsequent surveys. We also carried out a first-hand building damage survey in selected areas. The investigation of the strong-motion data set from the USGS Center for Engineering Strong Motion Data includes information from stations in Nepal that continued to function throughout the main shock and the several subsequent strong aftershocks of the 2015 earthquake. The third and fourth surveys were to collect
\end{abstract}

T. Ohsumi $(\bowtie)$

National Research Institute for Earth Science and Disaster Resilience (NIED), Tennoudai 3-1, Tsukuba 305-0006, Japan

e-mail: t_ohsumi@bosai.go.jp

Y. Mukai · H. Fujitani

Kobe University, Rokkoudai 1-1, Nada, Kobe 657-8501, Japan the every building damage survey in selected areas. The motivation behind the survey was to obtain ground truth data for the calibration and improvement of a wide-area damage estimation system that uses satellite data; the system is currently under development by National Research Institute for Earth Science and Disaster Prevention (NEID) and the Japan Aerospace Exploration Agency (JAXA). A survey of the degree of damage was conducted for every house in Sankhu and Khokana by the European Macroseismic Scale (EMS) 98. This report outlines the findings of this investigation team into various aspects of the earthquake disaster in the Kathmandu Valley. The motivation behind the survey was to obtain ground truth data for the calibration and improvement of a wide-area damage estimation system that uses satellite data. Field surveys confirmed that the severely damaged urban area was well detected by the decrease derived from the ALOS- 2 satellite SAR data. The higher classification accuracy for non-damaged area helps to detect the damaged urban area using this technique, immediately after a disaster.

Keywords Gorkha - Nepal earthquake · Kathmandu $\cdot$ Masonry $\cdot$ Ground truth

\section{Introduction}

An earthquake with a magnitude of $7.8\left(M_{w}\right)$ occurred at 11:56 Nepal Standard Time (NST), (local time) on 25 April 2015, in the central part of Nepal (Gorkha). 
The epicenter was east-southeast of Lamjung, $77 \mathrm{~km}$ south-west of Kathmandu, 28.15 at the north latitude and 84.71 at the east longitude, and the depth was $15 \mathrm{~km}$ (USGS). According to the statistics by The Nepal Police on 22 June the number of deaths 8660 and injured 21,952 for the main shock and deaths 172 and injured 3470 for the aftershock. It was also reported that $>5,000,000$ buildings and houses were damaged and about half those which of had collapsed. This earthquake was officially named as The 2015 Gorkha, Nepal earthquake, since the hypocenter was located in the Gorkha region.

A major aftershock with a moment magnitude of $7.3\left(M_{w}\right)$ occurred at 12:51 NST on 12 May 2015. The epicenter was $75 \mathrm{~km}$ north-east of Kathmandu and near the Chinese border, 27.82 at the north latitude and 86.08 at the east longitude, and the depth was $19 \mathrm{~km}$ (USGS).

We surveyed to the affected area during 26 May to 3 June and 17 to 24 to investigate the damage and collect data. The findings of this investigation undertaken by this team on the various aspects of the earthquake disaster in the Kathmandu valley. Third damage survey and fourth damage were conducted for every house in Sankhu on 17-18 Aug/29 Oct 2015 and in Khokana on 19-20 Aug/30-31 Oct 2015.

We found traditional construction methods are stronger than imagined. Many traditional earthquakeresistance technologies exist in Nepal. This is an important factor in maintaining traditional construction methods to preserve such technologies.

The maintenance of traditional buildings contributes not only to the maintenance of world heritage but also improvements in the earthquake resistance of cities. The problem of the masonry structure and in maintenance is shown in this study.

Surveys of building types and damage extent were conducted, for every house in Sankhu and Khokana, Kathmandu, after a second survey term. For building types, we used building classification surveys by the Japan International Cooperation Agency, commonly called JICA (2002). Building damage magnitudes were classified using European Macroseismic Scale (EMS)-98 (Grünthal 1998). A high-resolution image from March 12 (before the disaster) was obtained from Google Earth $^{\mathrm{TM}}$ prior to the survey. This image was used to identify the position of each building before the earthquake, based on which the damage to each building was estimated in accordance with EMS-98.
With the above approach, we determined damage in Sankhu and Khokana related to the 2015 Gorkha Earthquake in core areas, using the damage function indicated by JICA (2002) .

\section{Earthquake Recorded in Kanti Path (Katnp), Central Kathmandu}

The strong-motion data set from the USGS Center for Engineering Strong Motion Data (CESMD: http:// strongmotioncenter.org/cgi-bin/CESMD/iqr1.pl). Figure 1 shows the three components of acceleration and velocity recorded by the CESMD station at the US Embassy in Kathmandu, which recorded the $M_{w} 7.8$ main shock (06:11:26 UTC, $28.15^{\circ} \mathrm{N} 84.71^{\circ} \mathrm{E}$, $15.0 \mathrm{~km}$ deep). Figure 2 shows the three components of the tripartite response spectra of the main shock and aftershocks. The dominant periods in the Fourier spectra were approximately in the range of $4-5 \mathrm{~s}$ for magnitude 7 class events. However, for magnitude 5 class events, the dominant periods of the Fourier spectra were about $0.5 \mathrm{~s}$.

In Fig. 1, the vertical velocity motion waveform has two pulse-like ground motions. The main parts of the velocity waveform can be seen centered at two points: 45.08 and $53.07 \mathrm{~s}$. The difference between the rupture start time and arrival time for the S-wave is $8 \mathrm{~s}$. The dominant period of the body wave is about $4 \mathrm{~s}$.

These sizes can be estimated for each strong motion generation area (SMGA) by direct interpretation of body waves.

The methodology shows below;

$R=T_{p} \times V_{r}$

$V_{r}=0.72 \cdot V_{s}$

where $R$ Circular strong motion generation area, $T_{p}$ Pulse period, $V_{r}$ Rupture velocity, $V_{s}$ Shear-wave velocity

Thus, two SMGA might existed near the city of Kathmandu.

\section{Damage in Kathmandu Valley}

\subsection{Kathmandu}

At places along the Kathmandu Ring Road, reinforced concrete (RC) frame buildings were tilted damaged by the soft ground; however, most of the building damage 

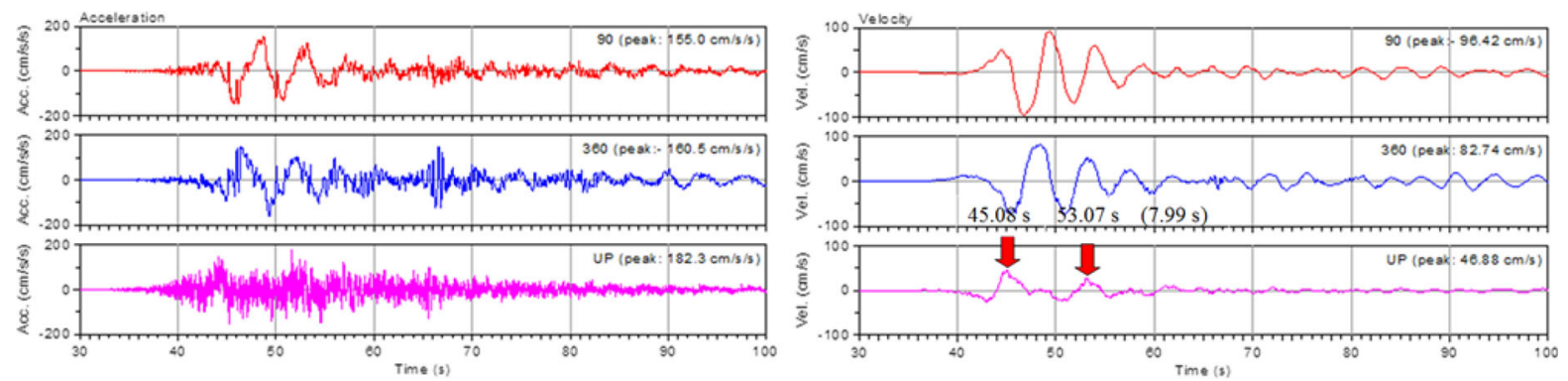

Fig. 1 Acceleration (left) and velocity (light) record of $M_{w} 7.8$ main shock

\section{1) $\mathrm{M7.8}, 25 \mathrm{Apr} ., 07: 05$ $27.84 \mathrm{~N}, 86.08 \mathrm{E}$}
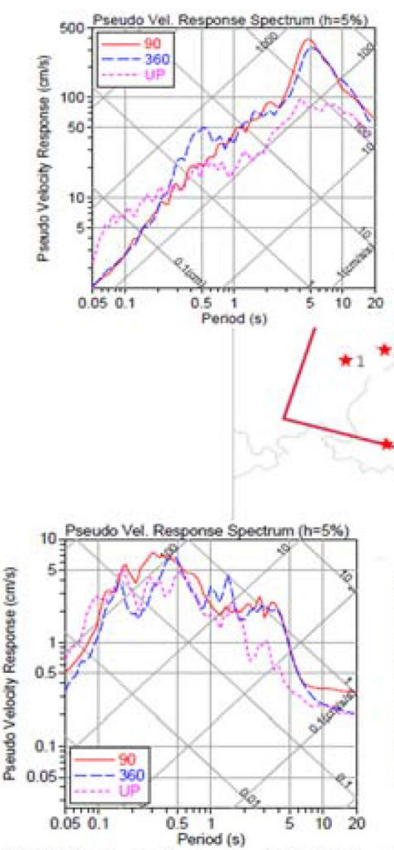

4) $\mathrm{M} 5.3,25 \mathrm{Apr}$., 08:55 $27.64 \mathrm{~N}, 85.50 \mathrm{E}$
2) M6.6, 25 Apr., 07:05 $28.19 \mathrm{~N}, 84.87 \mathrm{E}$
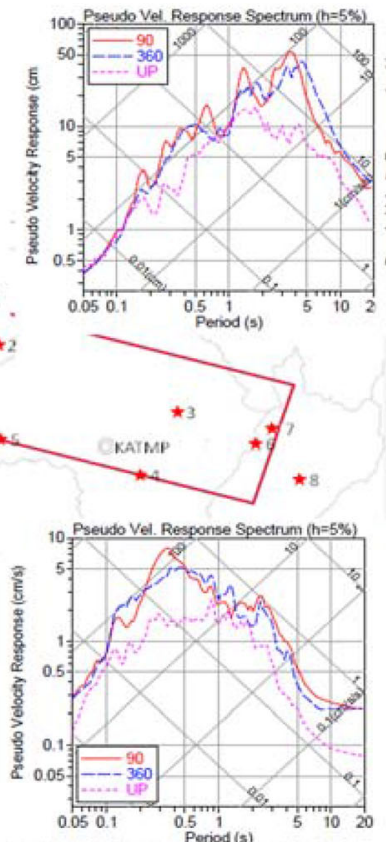

5)M5.6, 25 Apr., 23:16 27.81N 84.87E

Fig. 2 Response spectrum of main shock and aftershocks

in the city occurred in masonry buildings. At Gongabu, northwest of the Ring Road, many RC buildings were damaged; most of these were four to seven story structures. The damage was sometimes greater at locations with soft ground such as deltaic deposit near river branches (Fig. 3); however, some damage was also likely to have been caused by inappropriate construction methods. At Sitapaila, west of the Ring Road, some RC building collapsed at locations where the ground conditions on terraces

\section{3) M5.5, 25 Apr., 06:56 6) M6.7, 26 Apr., 07:09 27.91N 85.65E $27.78 \mathrm{~N}, 86.00 \mathrm{E}$}
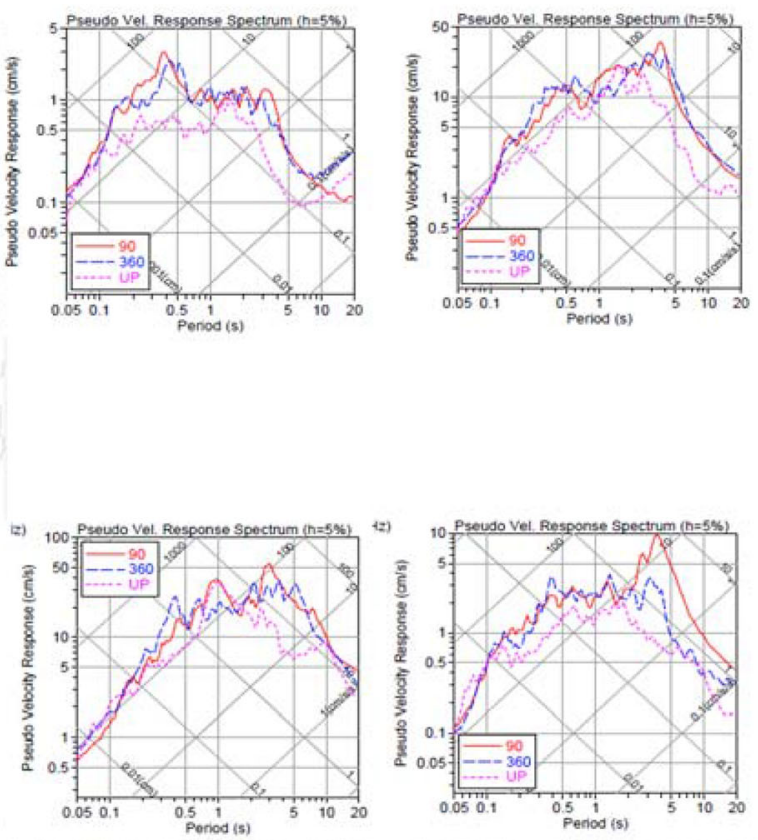

7)M7.3, 12 May, 07:36 $27.84 \mathrm{~N} 86.08 \mathrm{E}$

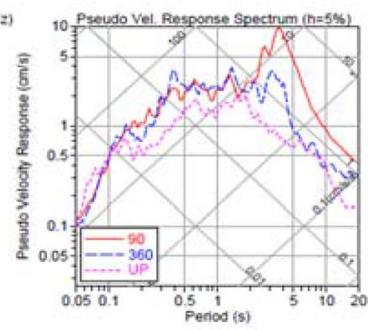

8)M6.3, 12 May, 07:36 27.62N 86.17E

were a bit stiff. At Balkhu, southwest of the Ring Road, RC frame buildings were tilted (Fig. 4). This is near the confluence of the Bagmati and Balkhu rivers, where collapsed buildings fell onto and destroyed a neighboring building (Fig. 5). The ground was soft in Balkhu because of the presence of riverbed sediments. Within our survey area, the liquefaction area was very limited. Building damage was caused by soft ground on the river branch (related to the 2015 Gorkha Earthquake), not by liquefaction. 
Fig. 3 At Gongabu, RC frame buildings were tilted $(\mathbf{a}, \mathbf{b})$. A shear crack in the first flower (c) (photo by $\mathrm{T}$. Ohsumi)
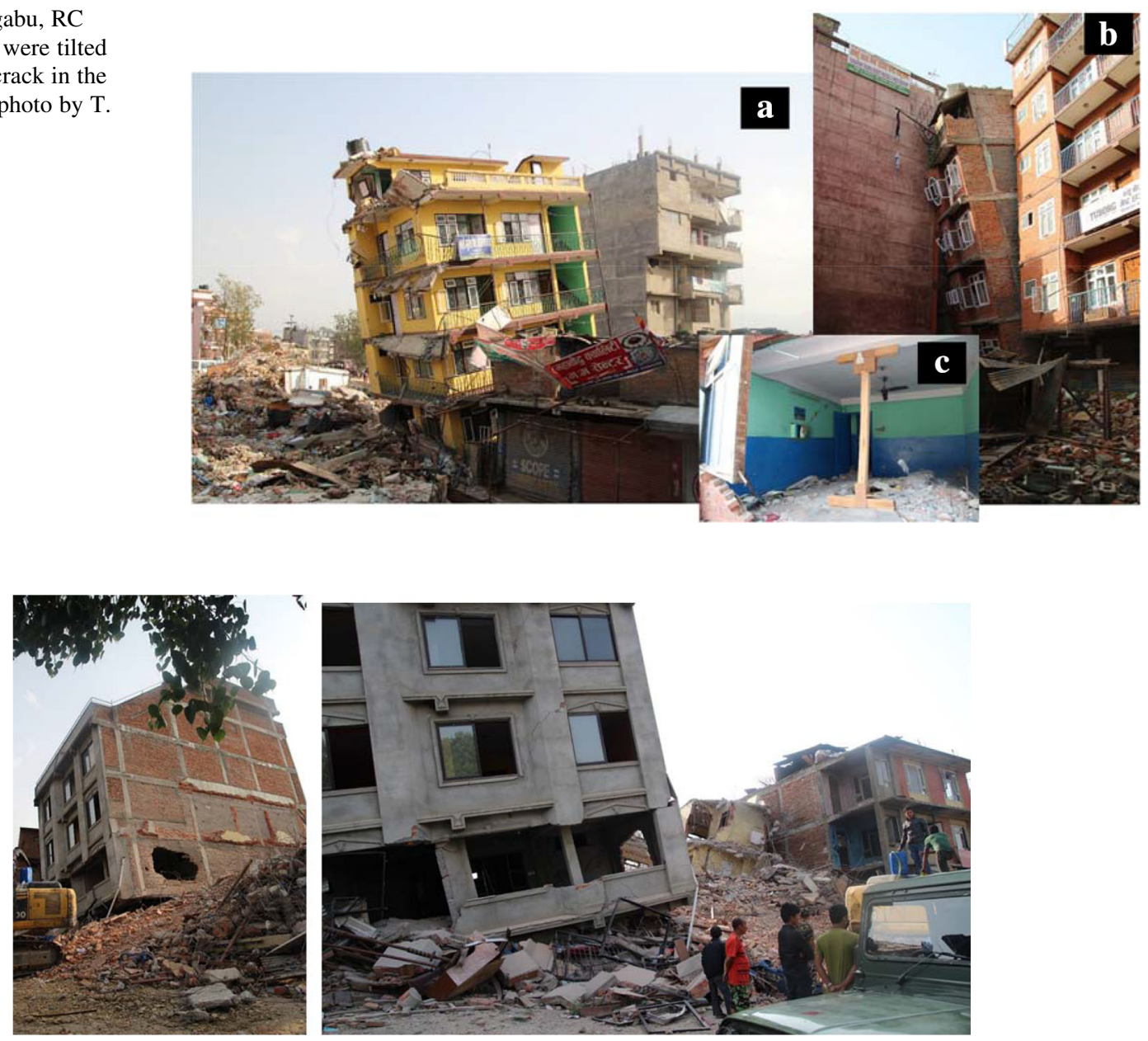

Fig. 4 At west side of the Ring Road in Kathmandu, RC frame buildings were tilted (photo by T. Ohsumi)

\subsection{Sanhkhu}

Sankhu is an old town and locating on a small hill in the north east part of the Kathmandu Valley. Houses damaged by the earthquake have been demolished. In general, RC buildings were partially damaged, whereas masonry buildings were severely damaged.

The difference in damage as a result of building type was remarkable. Damage in Sankhu was extensive. Brick and cement mortar houses without RC columns experienced a lot of damage. In contrast, the damage to RC structures-particularly those erected in recent years-was generally minor. These structures were mainly five to six story buildings. In contrast, many of the non-engineered masonry structures that experienced complete collapse or partial damage were two to four story buildings in Sankhu
(Fig. 6). Damage in non-engineered masonry structures was initiated by vertical cracks in the corners of the buildings, which contained no RC columns (Fig. 7a), the outer wall structures of such buildings were generally burned brick with cement mortar joints to withstand rain. In several cases, the inner walls of buildings are adobe bricks with mud mortar (Fig. 8b).

\section{Traditional Construction Methods in Kathmandu Vally}

\subsection{Chowks, a Type of Courtyard}

The traditional method of brick making is stronger than imagined. It is considered that buildings surrounding a courtyard have high rigidity. This is 
Fig. 5 At the branch point of the Bagmati River and the Transformor River, collapsed building (a) fell onto and destroyed the next building (b) (photo by T. Ohsumi). OpenStreetMap https://www.openstreetmap. org/

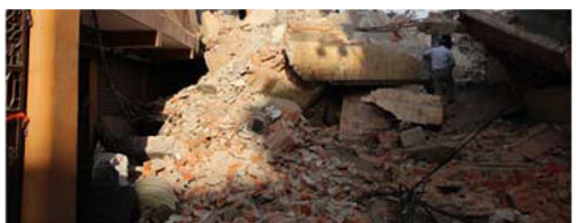

a

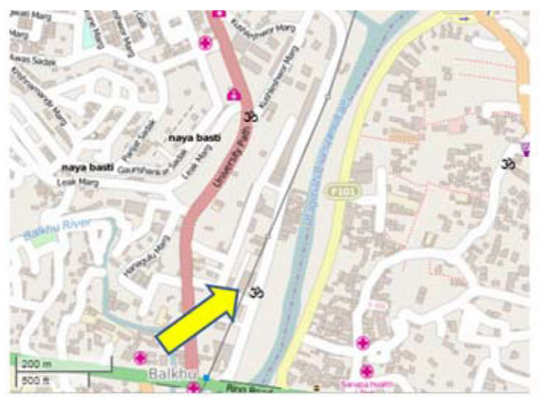

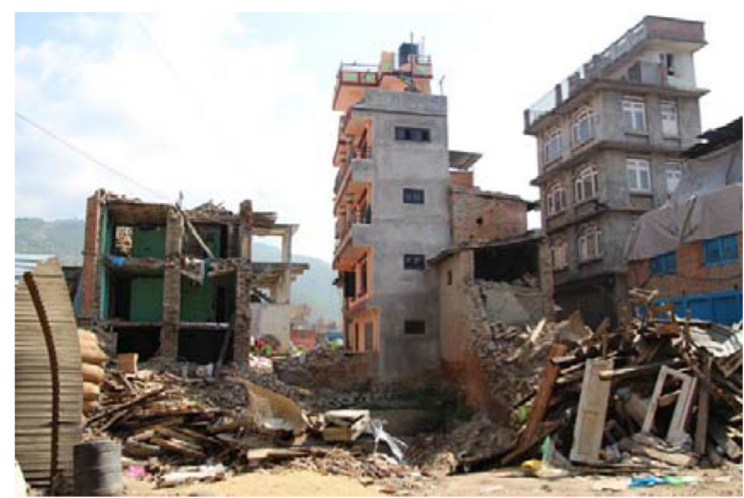

Fig. 6 RC buildings were partially damaged, the difference appears remarkable in Sankhu (photo by T. Ohsumi)

important to save the lost courtyard Fig. 8 shows typical courtyard in Lalitpur and Bhaktapur.

A chowk is a type of courtyard that is common in the community of Newar in Nepal. The chowk is characterized by a square or rectangular space surrounded by buildings on all sides. The surrounding buildings are built on a raised platform, called falcha. Opposite the main entrance on the ground floor is an area dedicated to the Guthi-Social Unify and other Gods with idols of deities. The chowk structure is excellent with respect to earthquake resistance. However, these traditional buildings are gradually becoming less common as a result of rebuilding (Fig. 9).
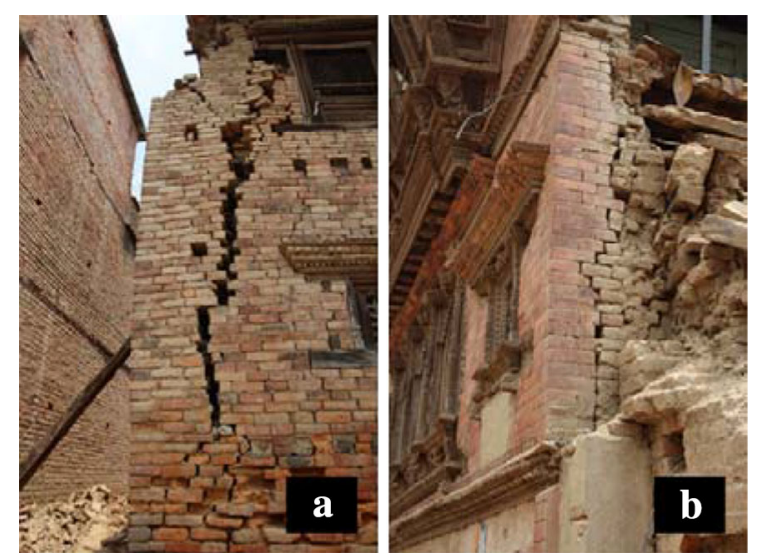

Fig. 7 A vertical crack in a brick masonry wall was generated from the corner (a). Structures having no RC columns on the corner (b) (photo by T. Ohsumi)

\subsection{Typical Masonry Building Four-Story Structures}

In urban core areas, four-story buildings dominate, and more than a third of the buildings are five stories or higher. The construction of the Nepalese traditional four-story house is shown in Fig. 10. These are mainly brick masonry structures, but many of them have been extended vertically by adding additional stories to the original three- or three and a half-story buildings. In addition, many of them are divided vertically for the 
Fig. 8 Building with a central courtyard/chowk in Lalitpur (a photo taken in 2001), b courtyard/chowk image
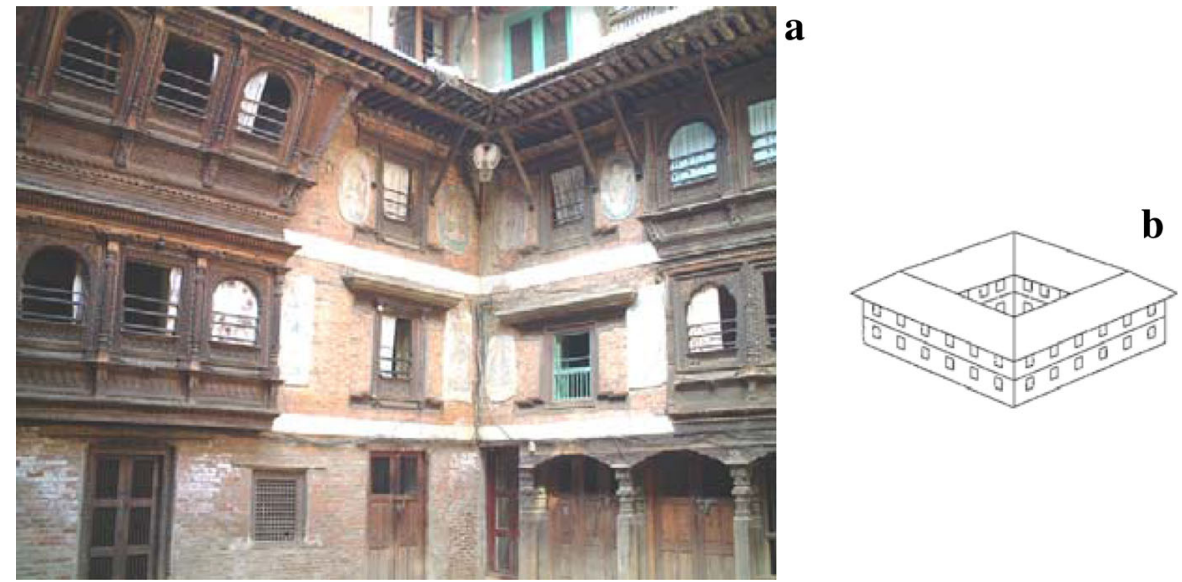

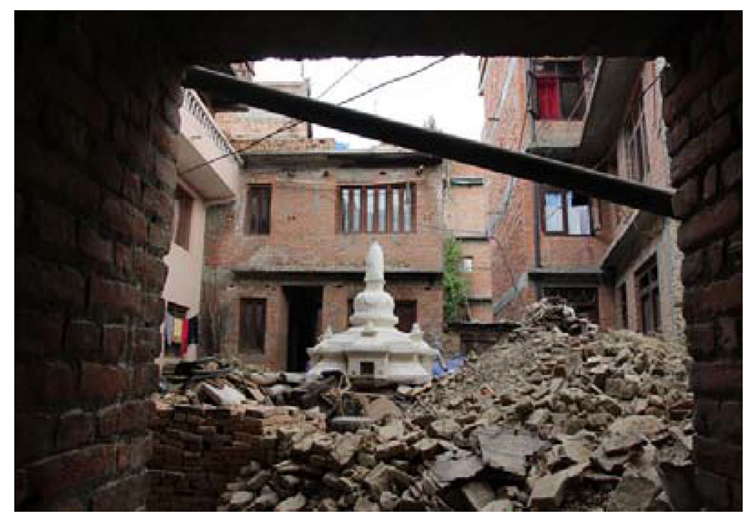

Fig. 9 Traditional buildings are gradually becoming less common as a result of rebuilding (photo by T. Ohsumi, taken after earthquake in Sankhu)

use of separate families because of the local custom of succession of property. This contributes to higher seismic risk, even if one does not consider the poor building technology actually adopted for the construction.

\subsection{The Timber Repair}

The traditional method of construction, which does not use metal with timber (Fig. 11) has prevented degradation for a long time. This type of construction should be repaired using traditional methods without resorting to modern methods. This traditional construction method resist motion throughout the structure during earthquakes (Fig. 12). The traditional structures caused brittleness transformations and defective corners of the structures related to the 2015 Gorkha

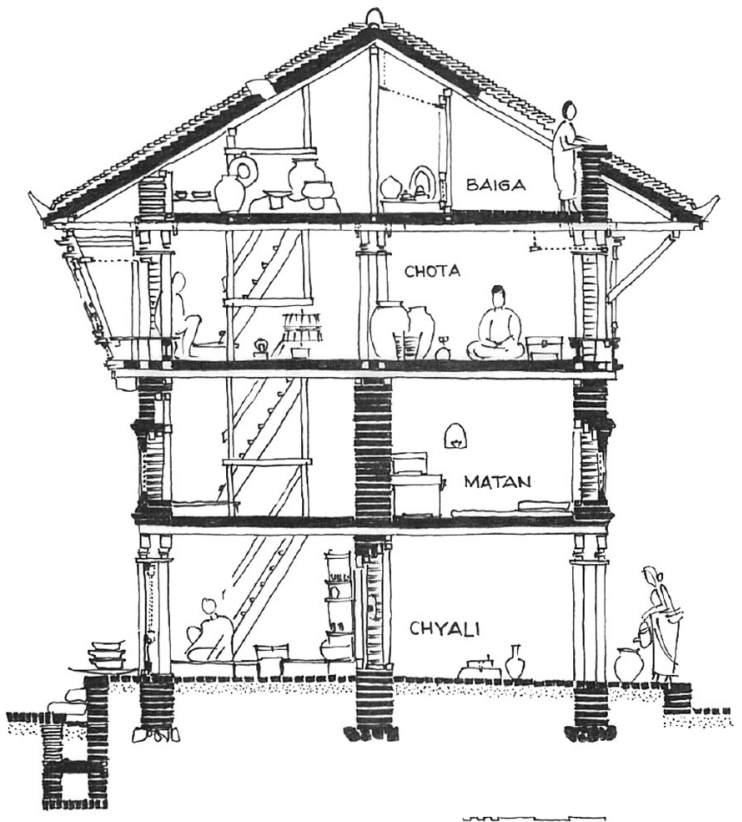

Fig. 10 Typical cross section of a multiple-story building (after Toffin 1991)

earthquake (Fig. 13). Reinforcement with such components as hold down hardware and battledore bolts is indispensable.

\subsection{The Latticed Window and the Outer Frame Effect}

A latticed window and an outer frame (puratva) surrounds door are reinforced the buildings (Fig. 14). The window and the door made with a tree have its own stiffness. The wooden frame is arranged with the 

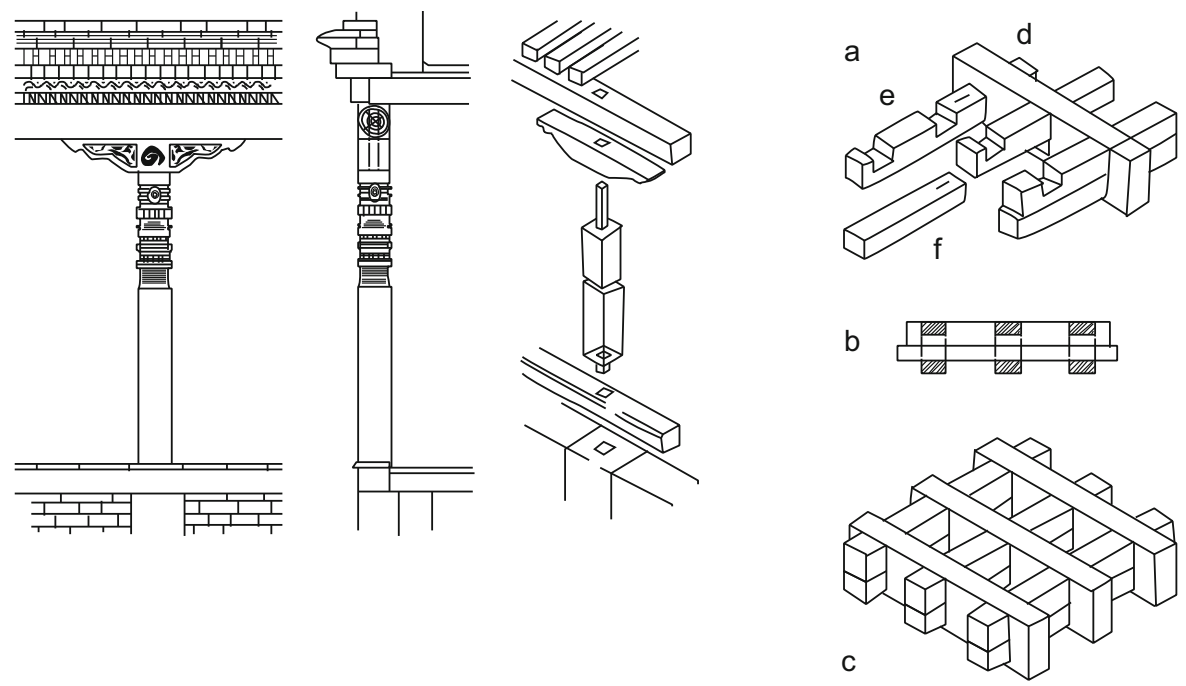

Fig. 11 Timber technology (after Toffin 1991) — detail of opening canage-a exploded, perspective; b transversal section; c perspective of assemblage elements; $\mathbf{d}$ main frame; e secondary frame; f wedge key

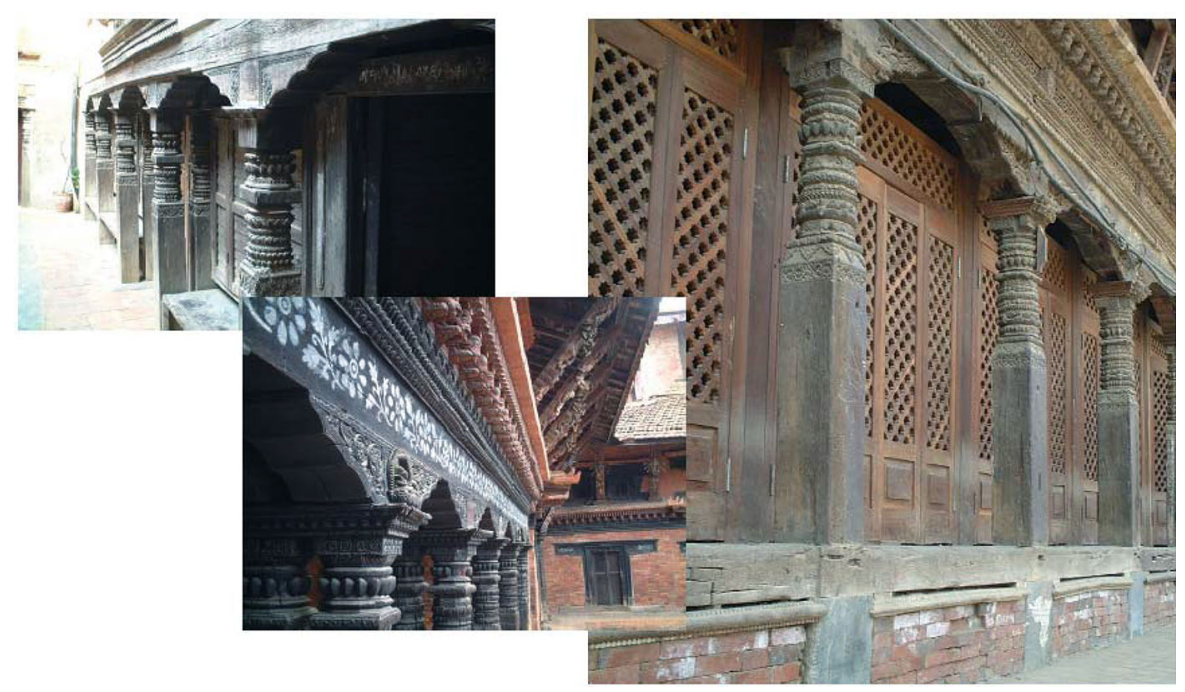

Fig. 12 Traditional construction method resist motion throughout the structure during earthquakes (photo by T. Ohsumi)

outside wall and the inside. The wooden frame and the door fixed from both sides has reinforced stiffness in an opening (Fig. 15). Shuttering windows (Pasahdhi) consists of a lower panel or planks inserted into a joint and locked in its position by a rail and a movable shutter. The shutter is fastened at the ceiling joints before the rail and panel are removed (Fig. 16).

\section{Manintenance Technology}

\subsection{Roof Repair}

Roof soil, which is cured clay/silt, prevents heat conduction from sunlight and is water resistant indoors (Fig. 17). Flying weeds cause the roof for long year. 
Fig. 13 Traditional structures caused brittleness deformations and defective corners of the building related to the 2015 Gorkha Earthquake in Khokana (photo by T.Ohsumi after the 2015 Earthquake)
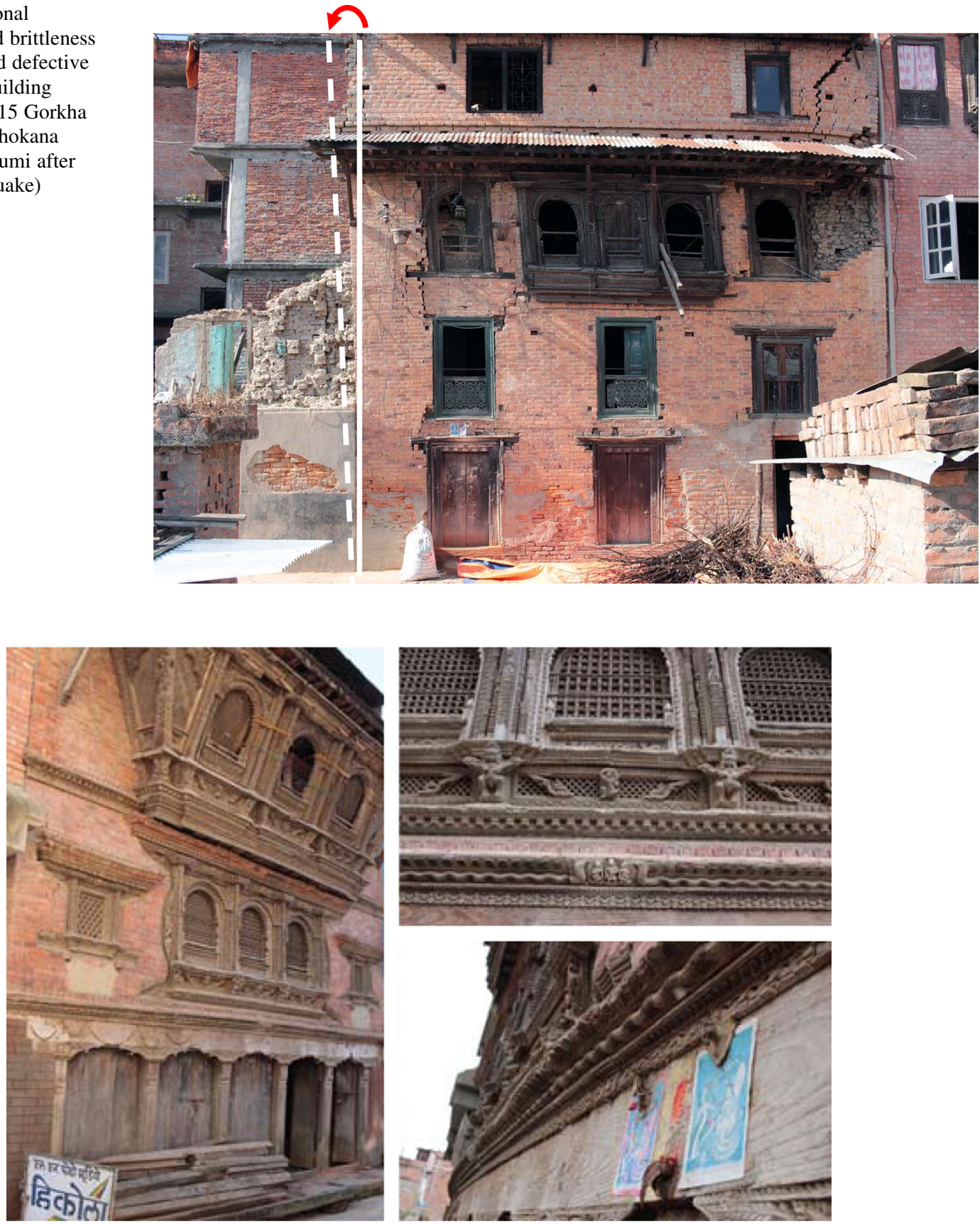

Fig. 14 Building constructed over 100 years ago that was slightly damaged by the Gorkha earthquake: (photo by T. Ohsumi; photo by T. Ohsumi, taken after Gorkha earthquake in Sankhu)

For the infiltration of rainwater, the building deteriorates. The roof renovation is important periodically.

Renovation of the temple's roof was carried out in 2015 (Fig. 18). Figure 19 shows a house roof renovation carried out in 2015.

\subsection{Renovation of the Royal Palace}

The Patan palace was renovated with assistance from the Kathmandu Valley Preservation Trust (KVPT) and the Sumitomo Foundation in 2013 (Fig. 20). Thus, in 
Fig. 15 Structural elements of a window: a and Section of a door: $\mathbf{b}$ details of sill, lintel, door leaves and bolts (after Gutschow et al. 1987)

Fig. 16 Shuttering window: a (photo by $\mathrm{T}$. Ohsumi) and section of a shuttering window: b (after Gutschow et al. 1987)

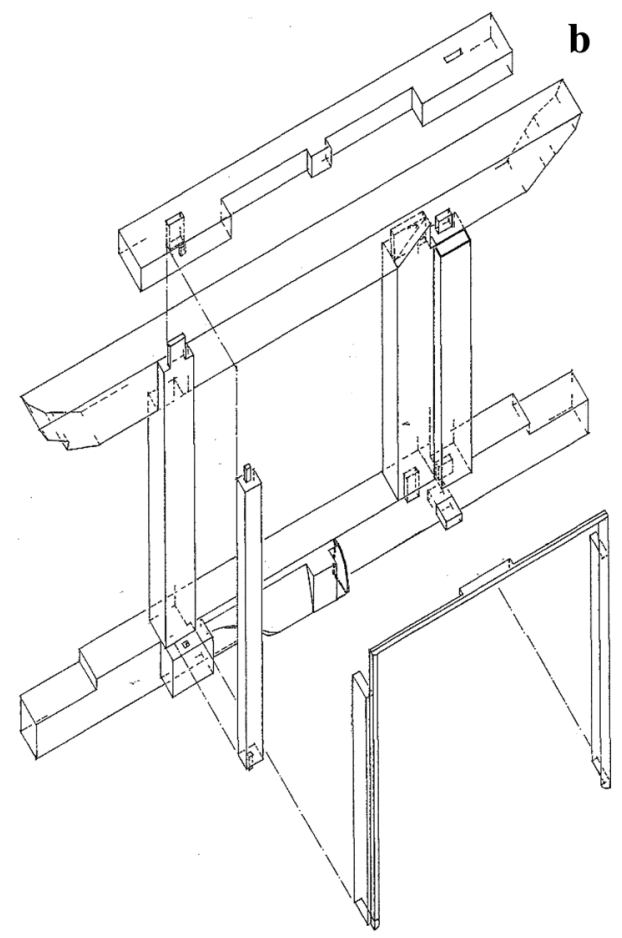

$\mathbf{a}$
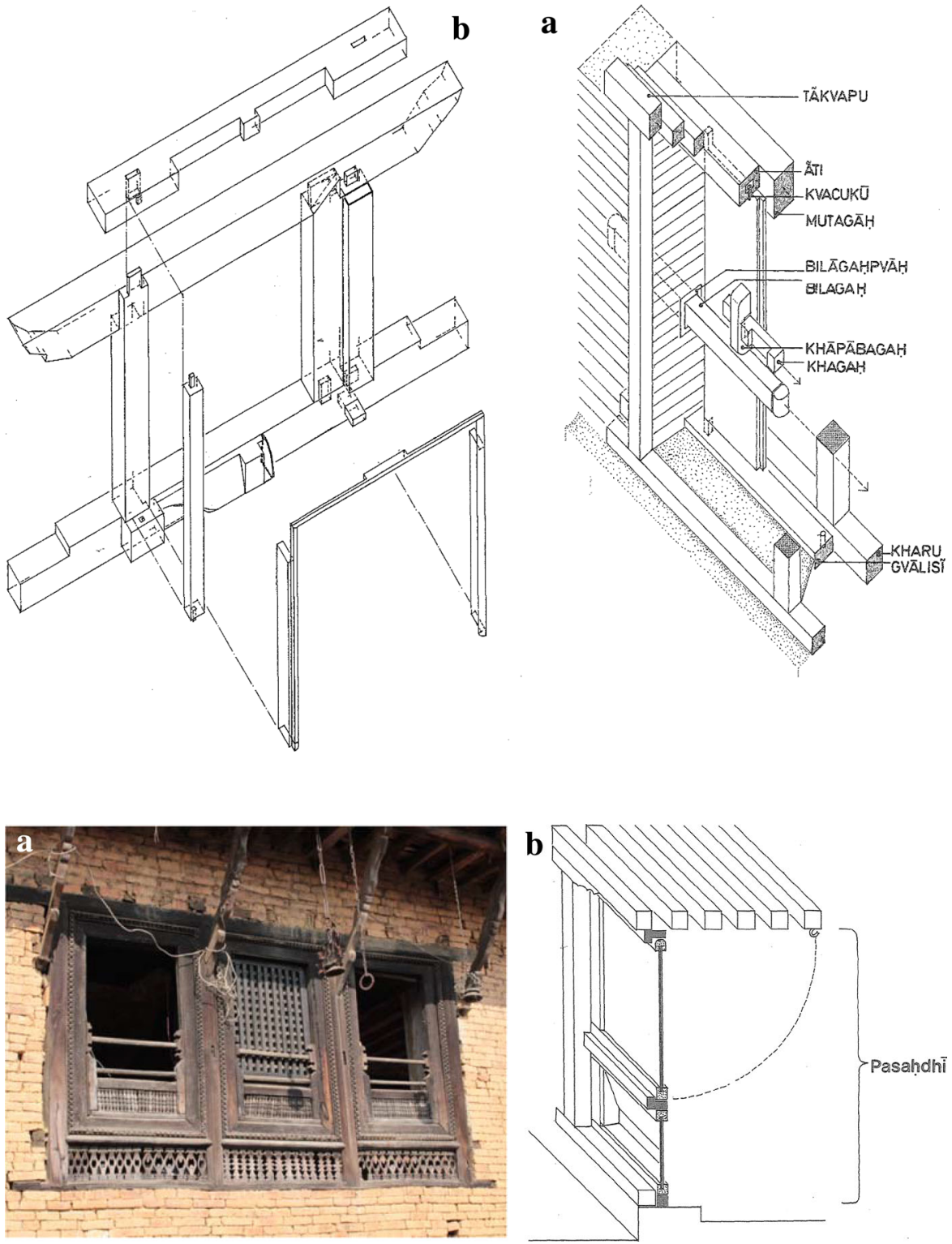

Patan, after the earthquake, this palace had only partial damage at the top of the structure (Gajur and Baymvah).

\section{Building Types in the Kathmandu Valley}

Hazards and damage were analyzed in a study on earthquake disaster mitigation in the Kathmandu Valley (JICA 2002). To estimate damage to buildings from the earthquake, a building inventory, especially one with the distribution of buildings by structural type, is necessary. Building structure types were grouped into the following seven classes based on the inventory.

ST Stone

AD Adobe

BM Brick with mud mortar, poorly built

BMW Brick with mud mortar, well built

BC Brick with cement or lime mortar

RC5 Reinforced concrete (RC) frame with masonry of four stories or more 


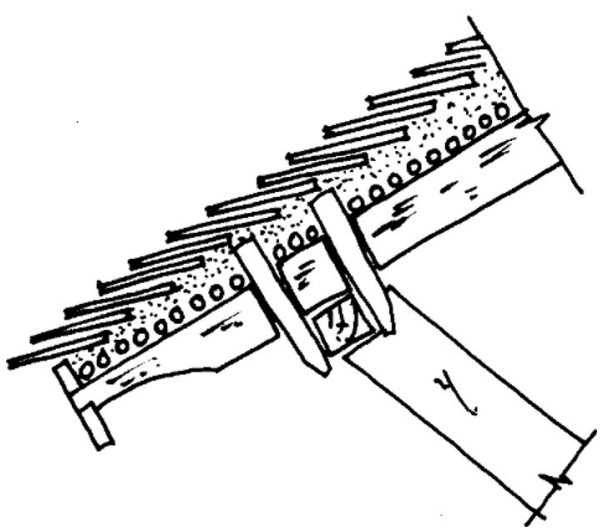

Fig. 17 Typical roof cross section. (courtesy of Assistant Prof. Ram Prasad Suwal with Nepal Engineering College)

RC3 RC frame with masonry of three stories or less

According to the inventory, we determined building types and their distribution in the settlement types of Kathmandu Valley. The main types are ST, AD, BM, BC and RC. Newer types (BC and RC) are predominant in the central and rapidly developing areas, and other types (ST, AD and $\mathrm{BM}$ ) are predominant in rural or older core areas with dense population.

(a) $\mathrm{RC}$

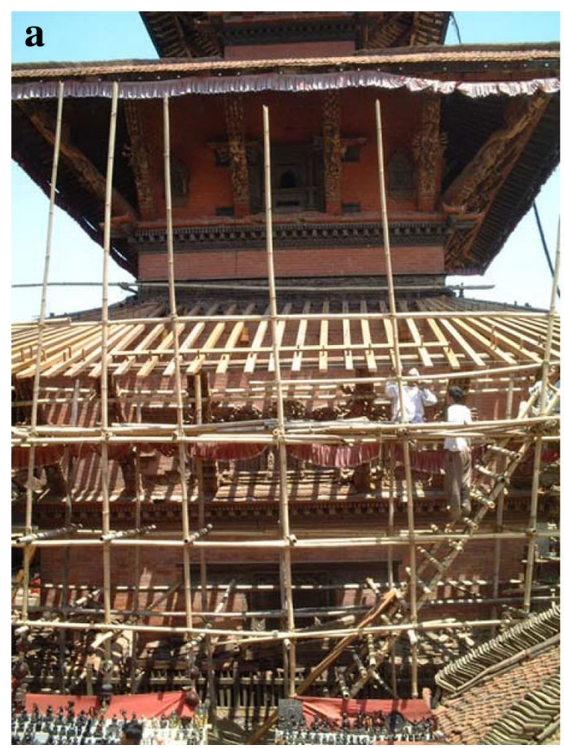

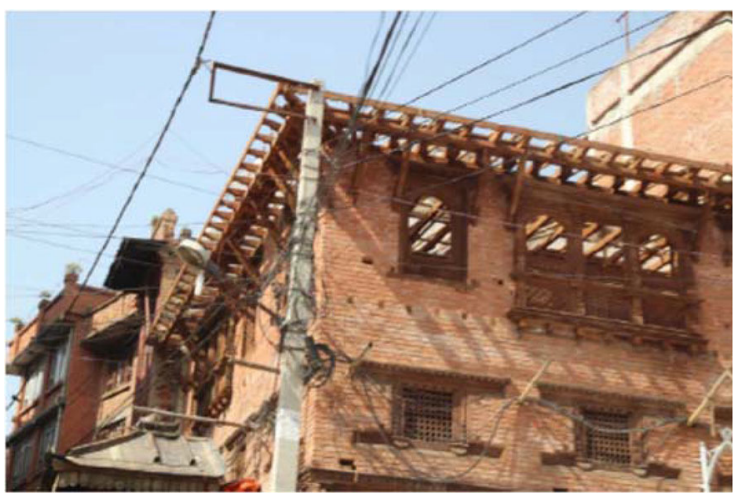

Fig. 19 Renovation of a house roof was carried out in 2015 (photo by T. Ohsumi)

RC buildings have been constructed in the last 30 or 40 years in urban areas. Although most building owners and constructors believe that RC buildings are safer and sufficiently strong, most buildings were designed without a structural engineer and were built with supervision by unskilled craftsmen or masons who had no fundamental practice or structural knowledge of RC work. The initial plan including such items as the size of columns and beams was probably for three-story buildings, but current RC buildings extend four to six stories without strengthening of columns and beams. This may be attributed to rapid increase of

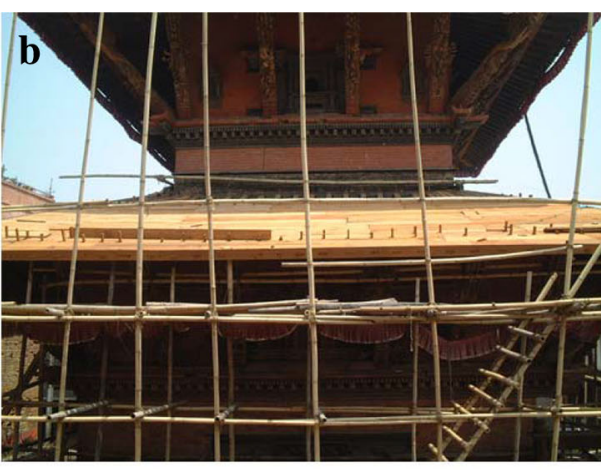

Fig. 18 Renovation of a temple's roof was carried out in 2015 a installation of timber rafters, b hand wood planking (photo by T. Ohsumi) 

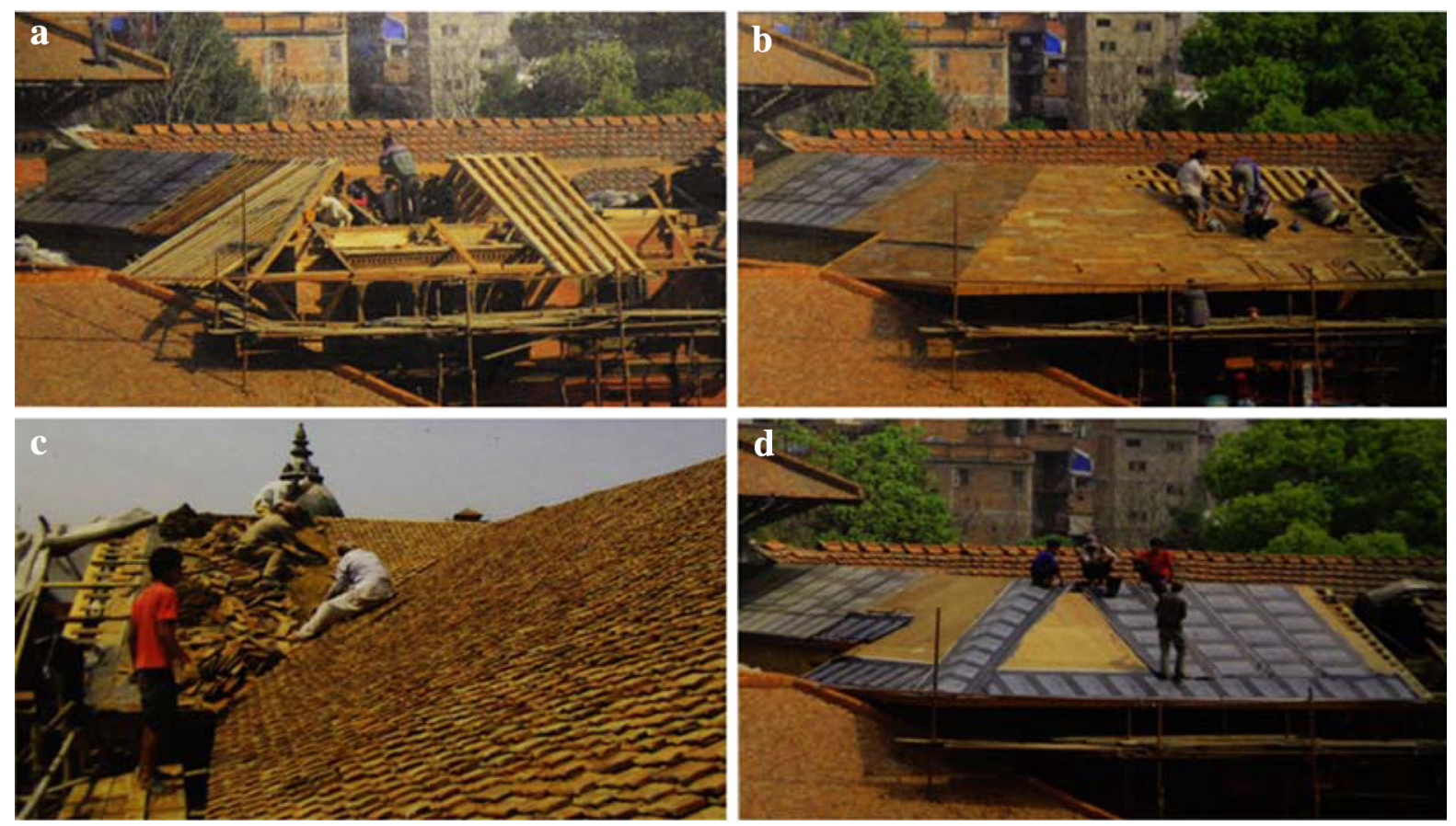

Fig. 20 Renovation of the structure and the covering of the roof was carried out in 2011: a (top left) installation of timber rafters, b hand wood planking, $\mathbf{c}$ waterproof membrane, $\mathbf{d}$ traditional

terracotta roof tiles on a mud bed (from information plate at the Patan Museum)

the urban population. Walls of the widened floors are supported by cantilever beams and are located outside the RC frames. The latter case has particularly great fragility in case of a great earthquake.

\section{(b) $\mathrm{BC}$ and $\mathrm{BM}$}

$\mathrm{BC}$ buildings, also constructed in the past 30 or 40 years, comprise about half the buildings in the valley. This type of building is still weak regarding horizontal rigidity, owing to poor workmanship and lack of structural consideration of the joints from wall to wall, wall to wooden floor and roof, and nonintegration of the masonry wall itself. Although buildings of this type that are less than four stories are generally constructed with suitable workmanship and adequate wall balance, those more than four stories tall have great fragility during a powerful earthquake.

BM buildings remain in urban and rural areas. These buildings have very poor horizontal rigidity because of low bond strength and strong absorption of moisture in mud joints, wooden floors and roofs. During a great earthquake, BM buildings of less than

three stories appear fragile and those of three or more are even more fragile.

\section{(c) $\mathrm{AD}$ and $\mathrm{ST}$}

$\mathrm{AD}$ and ST buildings have great fragility during a moderate earthquake.

\section{Classification of Damage to Masonry Buildings}

Table 1 shows EMS-98, which is the European standard. According to this, Grades 1-5 are defined below.

Grade 5 Very heavy structural damage

Grade 4 Very heavy structural and non-structural damage

Grade 3 Moderate structural damage and heavy non-structural damage

Grade 2 Slight structural damage and non-structural damage

Grade 1 No structural damage and slight nonstructural damage 
Table 1 Classification of damage to masonry buildings by EMS-98 (Grade1-5) (Grünthal 1998)

Classification of damage to masonry buildings

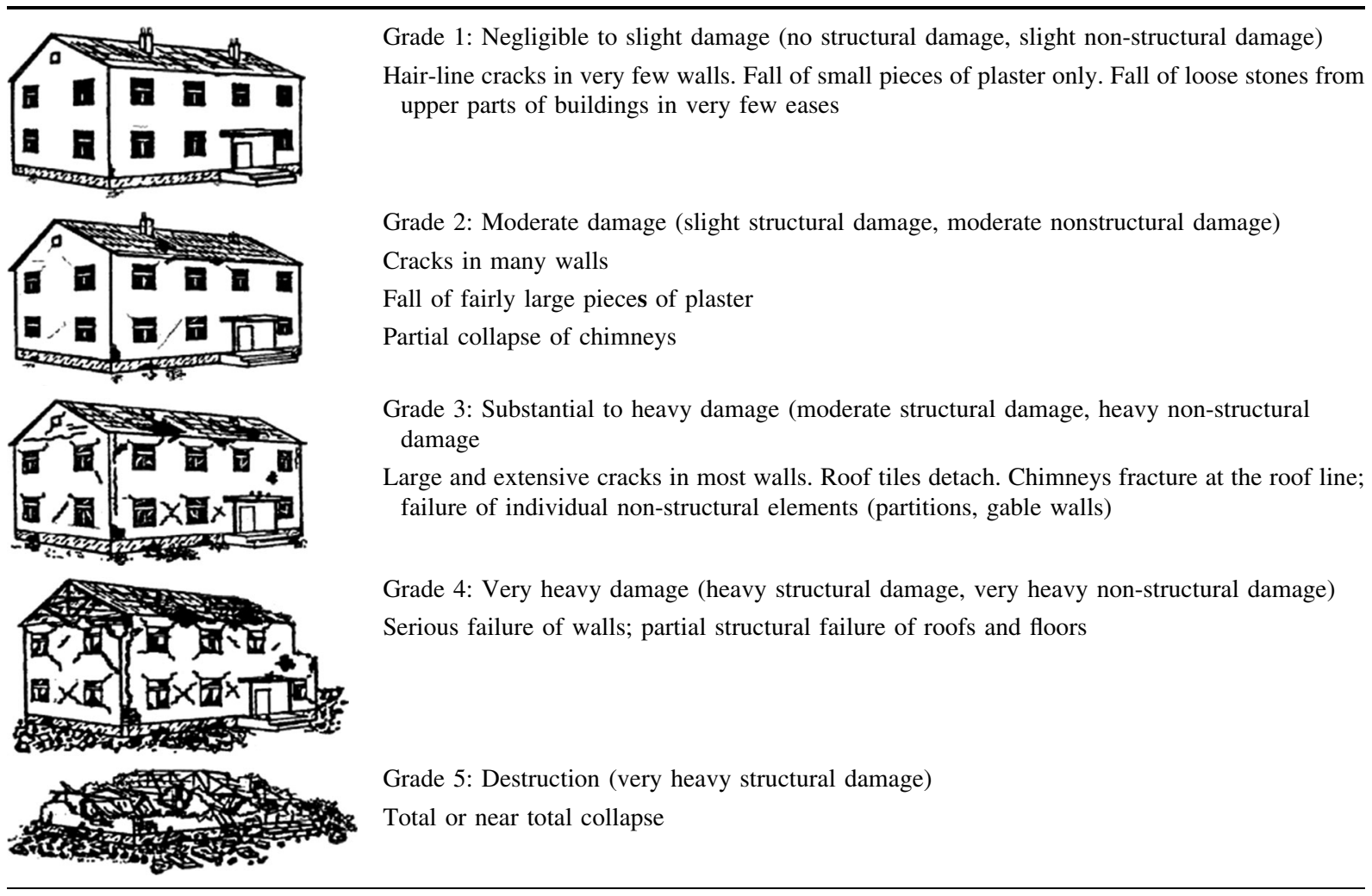

According to JICA (2002), "Collapse” and "Damage" were defined as below.

Collapse Collapsed or un-repairable (unsuitable for living)

Damage Collapsed or un-repairable (unsuitable for living) $+1 / 2$ repairable (available for temporary living)

This standard is difficult to correspond with Nepalese building conditions. Figure shows the building state of the site after the earthquake. In this study, Grade 5 or upper Grade 4 was determined by complete or non-complete collapse.

Grade 3 or upper Grade 4 was determined by moderate structural damage or not enough. A grade $>3$ was not determined for ground truth distinction by a satellite image, and was assigned a corresponding category.

\subsection{Survey of Building Damage in Sankhu Core Area}

This town was the ancient trade route with Tibet. Many Tibetan is living even at present. However these, buildings lose a source of income by present and decline, and are superannuated, and a renovation is not performed.

The difference in damage between the various building types is remarkable. Generally, the damage in Sankhu was extensive. Brick and cement mortar houses without RC columns had considerable damage, whereas damage to RC structures-particularly those erected in recent years-was generally minor. These latter structures were mainly five- to six-story buildings, whereas many of the non-engineered masonry structures that experienced complete collapse or partial damage had two to four stories. 
7.2 Survey of Building Damage in Khokana Core Area

Khokana is a traditional old town on a small hill in the southwestern Kathmandu Valley. It is a municipality in the Lalitpur District of Bagmati Prefecture, central Nepal, $\sim 10 \mathrm{~km}$ south of the city of Kathmandu.

According to an interview survey of the inhabitants, all buildings collapsed during the 1934 Bihar Earthquake in Khokana, except for one, which is being renovated. Thus, the historical buildings are $<80$ years old. Well-built historical buildings had expensive improvements for earthquake resistance, which included mixing plaster with mud joints.

\subsection{Survey of Damage for Every House in Sankhu and Khokana}

NIED and JAXA surveyed of damage for every house in Sankhu and Khokana (Ohsumi et al. 2015; Watanabe et al. submitted). A survey of the degree of damage was conducted for every house in Sankhu and Khokana by the European Macroseismic Scale (EMS)-98.

Damage extent was surveyed for every house in Sankhu on August 17-18, 2015 (Fig. 21a) using EMS98. A high-resolution image from March 12 (before the disaster) was obtained via Google Earth ${ }^{\mathrm{TM}}$ prior to the survey. This image was used to identify the position of each building before the earthquake, based on which the extent of damage to each building was estimated in accord with EMS-98.

Khokana was once Newari village and has retained its tradition and culture as a World Heritage Site in Nepal. A damage survey was conducted for every house in Khokana on August 19-20, 2015 (Fig. 21b).

We performed a helicopter and unmanned aerial vehicle (UAV) photogrammetry survey in Sankhu and Khokana, to map buildings and damage related to the 2015 Nepal Earthquake. NIED and National Society for Earthquake Technology (NSET) Nepal will use the data for research on building damage distribution, calibration of satellite imagery by ground truth data, and more detailed risk assessment of cities and rural communities as a survey in addition to the ground truth survey.

3D digital surface models of buildings will be created to measure building heights and shapes. Raw photos with oblique views can be used to investigate damage in more detail and structures. This technique was applied to the helicopter and UAV investigation. The helicopter flight was used for a photogrammetry survey of Sankhu on 20 Aug 2015. We used a helicopter (Bell Jet Ranger 206B).

The UAV flight was used for a photogrammetry survey of Khokana on 23 Nov 2015. We used a compact UAV, a battery-powered aircraft with onboard digital camera in auto-pilot mode to take aerial photos from 50 to $150 \mathrm{~m}$ above ground. The craft cruises at a speed $\sim 60 \mathrm{~km} / \mathrm{h}$ for about $20 \mathrm{~min}$, covering an area of $2 \mathrm{~km}^{2}$ in one flight. Pictures are processed by photogrammetry software to create Orthomosaic photos for mapping. Safety of the flights and compliance with regulations were of primary importance. Our fixed-wing foam aircraft is much safer than popular multi-rotor drones. It will not injure people if it crashes because: (1) the fuselage is made of soft Styrofoam; (2) the propeller is rear-facing; and (3) it can glide when falling. Autopilot flight can be programmed to avoid prohibited zones and is above the height limit directed by the Civil Aviation Authority.

Figure 22a, b show the survey of building type classification for every house in Sankhu and Khokana. The number for damage extent of each building type for every house is shown in Tables 2 and 3. The difference in damage by building type was remarkable. Brick and cement mortar houses without RC columns experienced substantial damage. In contrast, damage to RC structures, particularly those erected in recent years, was generally minor.

The total number of buildings for each area are shown in the upper stage, and the percentages of each item are shown in the lower stage. There was no damage to $94 \%$ of the surveyed RC buildings. From the comparison of $\mathrm{BM}$ and $\mathrm{BC}$, the collapse ratio was improved by $27 \%$ in Sankhu and $16 \%$ in Khokana for $\mathrm{BC}$ houses. There was $0 \% \mathrm{BM}$ Well with very heavy structural damage in both areas.

\subsection{Completion with Fragility Curves}

JICA (2002) study defining fragility curves for estimating damage to buildings was to determine the relationship between damage ratio and ground acceleration for each building type. These curves refer to the graph showing this relationship. In this study, the 

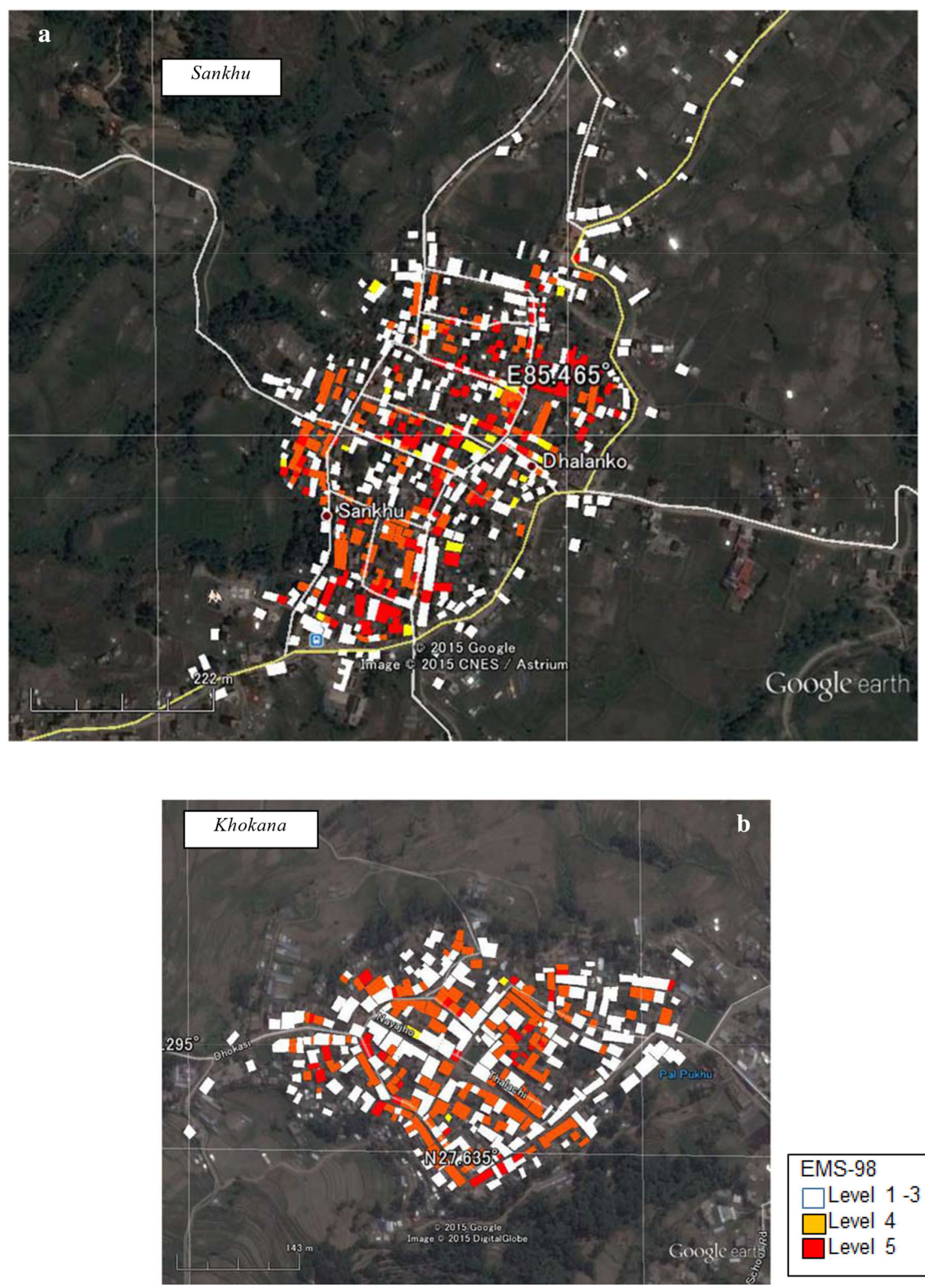

EMS-98

$\square$ Level 1-3

$\square$ Level 4

Level 5 
4Fig. 21 Survey of damage extent for every house in Sankhu (a), and Khokana (b) (Ohsumi et al. 2015; Watanabe et al. submitted)

curves for buildings in the Kathmandu Valley were determined as shown in Fig. 23a, b.

In the aforementioned JICA study, fragility curves for buildings in the valley were adjusted by calibrating existing fragility curves for Indian buildings from Arya (2000) and those for West Nepal from a UNDP/ UNCHS (1994) study. For this calibration, damage from the 1988 Udayapur earthquake cited in Murakami et al. (1990) and Dikshit (1991) were analyzed. These papers present very large seismic intensity distributions compared to the expected peak ground accelerations. We reanalyzed the intensity considering building weakness in our damage area, most of which
Fig. 22 Survey of building type for every house in Sankhu (a), and Khokana (b)
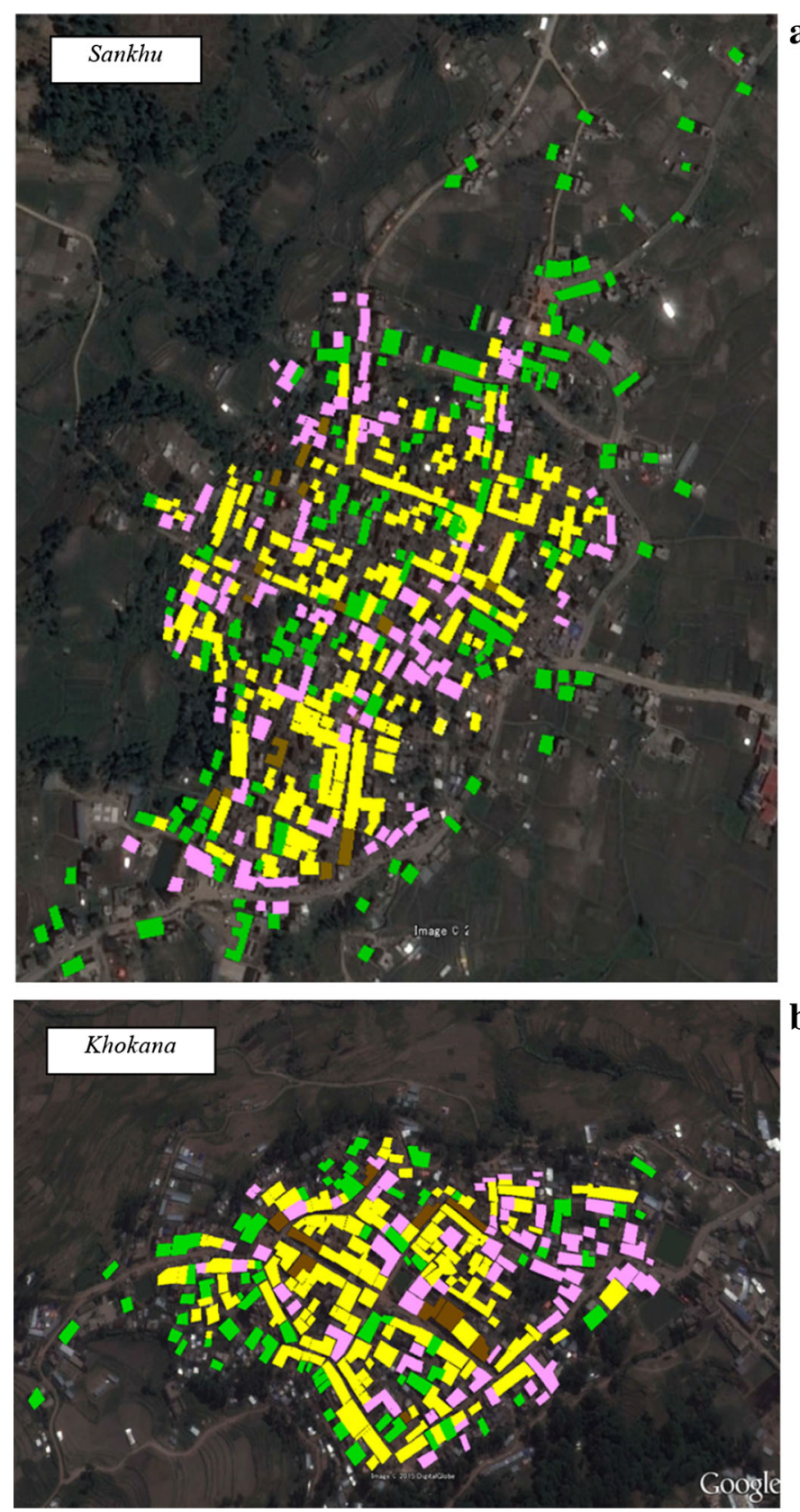

b

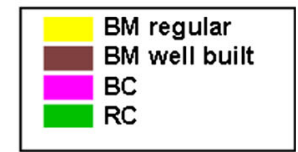


Table 2 EMS level for each ratio and building type in Sankhu

Table 3 EMS level for each ratio and building type in Khokana

\begin{tabular}{lcccc}
\hline & EMS-level 1 & EMS-level 2-3 & EMS-level 4 & EMS-level 5 \\
\hline RC & 144 & 1 & 9 & 0 \\
$\%$ & 94 & 0 & 6 & 0 \\
BC & 76 & 5 & 23 & 15 \\
$\%$ & 64 & 4 & 19 & 13 \\
BM well & 9 & 3 & 2 & 0 \\
$\%$ & 64 & 22 & 14 & 0 \\
BM & 50 & 13 & 71 & 90 \\
$\%$ & 22 & 6 & 32 & 40 \\
\hline
\end{tabular}

\begin{tabular}{lllcc}
\hline & EMS-level 1 & EMS-level 2-3 & EMS-level 4 & EMS-level 5 \\
\hline RC & 67 & 0 & 4 & 0 \\
$\%$ & 94 & 0 & 6 & 0 \\
BC & 54 & 0 & 17 & 2 \\
$\%$ & 74 & 0 & 23 & 3 \\
BM well & 7 & 0 & 4 & 0 \\
$\%$ & 64 & 0 & 36 & 0 \\
BM & 39 & 3 & 75 & 28 \\
$\%$ & 27 & 2 & 52 & 19 \\
\hline
\end{tabular}
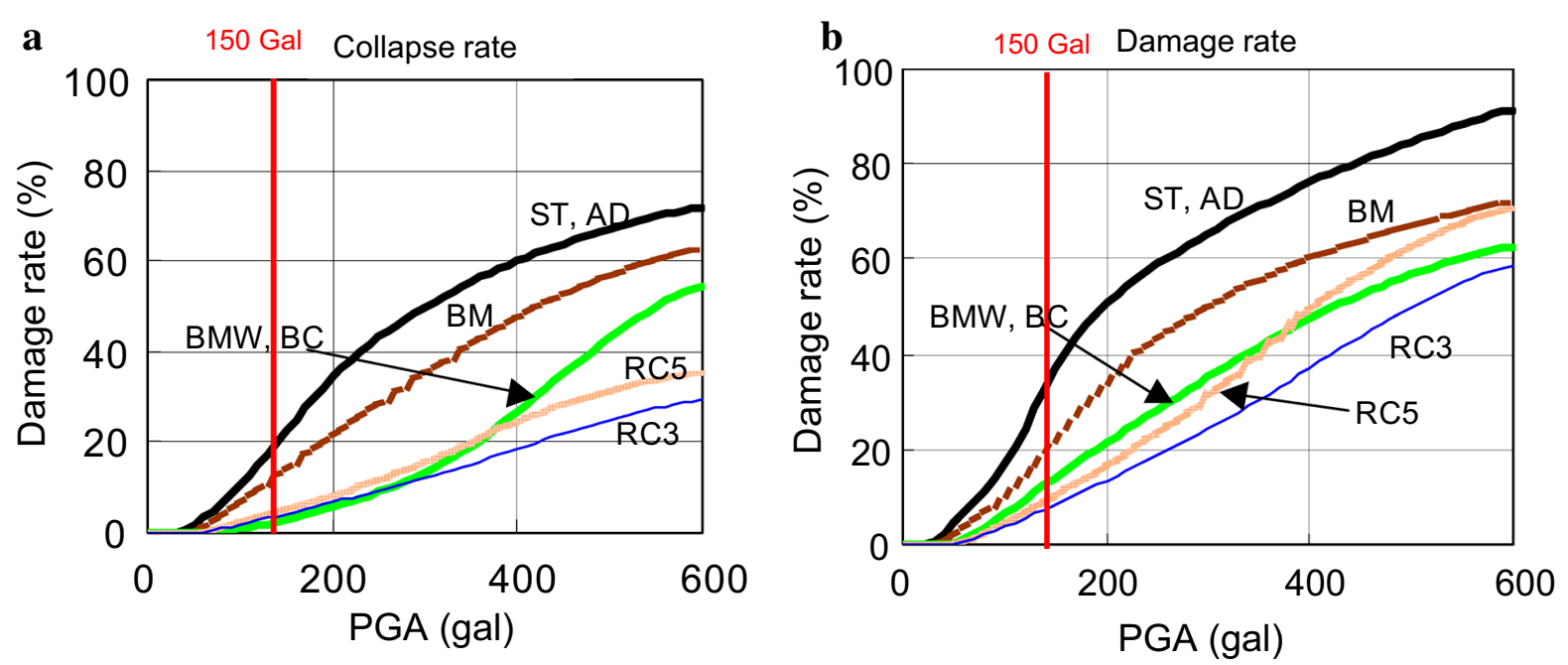

Fig. 23 Fragility curves of relation between damage rate and peak ground acceleration. a Damage rate, b Collapse rate

are $\mathrm{AD}$ or poor BM. Fragility curves of the relationship between damage rate and peak ground acceleration for each building type are shown in Fig. 23.

In the 2015 Gorkha Earthquake, there were no acceleration observation points in Sankhu and Khokana. The USGS maximum acceleration record was
$160 \mathrm{Gal}$ at the US embassy in the city of Kathmandu. The distance between that embassy and Sankhu is $\sim 15 \mathrm{~km}$, and that between the embassy and Khokana is $\sim 5 \mathrm{~km}$. According to Takai et al. (2015), the main shock in the observation results was $151 \mathrm{Gal}$ at Lalitpur and $146 \mathrm{Gal}$ at Thimi. Estimation of main 
shock acceleration values was $150 \mathrm{Gal}$ in Sankhu and Khokana.

Damage ratio of $\mathrm{RC}$ is $7-8 \%$ and damage ratio of $\mathrm{BM}$ is the $20 \%$.

Graed 5, damage ratio of $\mathrm{RC}$ is $0 \%$, damage ratio of BM is $40 \%$. In Khokana, damage ratio (Table 4) of $\mathrm{RC}$ is $6 \%, \mathrm{BM}$ is $70 \%$. Collapse ratio of $\mathrm{RC}$ is $0 \%$, $\mathrm{BM}$ is $20 \%$. The damage curved line of $\mathrm{BM}$ is exceeded the damage curved line of ST, AD.

$\mathrm{BM}$ is composite structure including the sun-dried brick (AD). The building classification is different in ages and referred earthquakes (i.e., the 1934 Bihal Earthquake, the 1988 Udayapur Earthquake).

The complicated composite structure is being classified in BM by the damage function. On the other hand, $\mathrm{RC}$ is actual damage rate and the damage function rate are good agreement (Table 4).

\subsection{SAR Analysis}

In the severely damaged core area, the principal mechanism of microwave radar backscattering changes from double-bounce to rough-surface scattering. This change corresponds to a decrease of coherence $(\gamma)$ in synthetic aperture radar (SAR) imagery observed before and after the disaster (Fig. 24). The value of $\gamma$ represents the similarity between two images. A decrease in $\gamma$ was determined in the data obtained over Sankhu and Khokana by the Japanese SAR satellite ALOS-2, and this was used to delineate severely damaged urban areas. Field surveys confirmed that damaged areas were effectively detected by a decrease in $\gamma$ (Watanabe et al. submitted).

Figure 25 shows the full view area as a Google Earth image, including $(a)$ the Timi, Bhaktapur and Sankhu core areas, and $(b)$ the Kirtipur, Khokana and Bungamati core areas. The damaged core area is

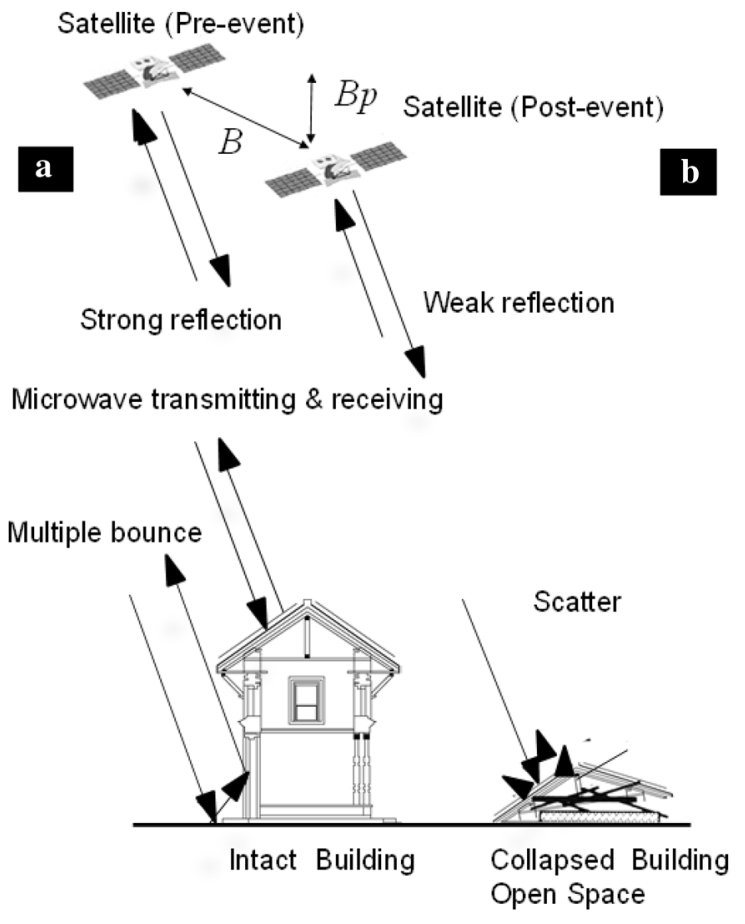

Fig. 24 Whole interferogram obtained by the analysis. a Preevent, b Post-event

identified using the coherence change $(\Delta \gamma)$ obtained before the disaster $\left(\gamma_{\text {pre }}\right)$ and between the disasters $\left(\gamma_{\text {int }}\right)$.

Figure 26 shows regions of bright reflections within severely damaged core areas such as Timi, Bhaktapur and Sankhu. Figure 27 shows the coherence magnitude and a survey of damage extent for every house in Sankhu. The decrease in coherence $(\gamma)$ in the SAR imagery observed before and after the disaster readily facilitated detection of damage in the region.

Figure 28 shows regions of bright reflections within severely damaged core areas such as Khokana and Bungamati. Figure 29 shows the coherence magnitude
Table 4 Fragility curves (JICA, 2002) and damage and collapse rate

\begin{tabular}{llllll}
\hline & \multicolumn{2}{l}{ Damage rate } & & \multicolumn{2}{l}{ Collapse rate } \\
\cline { 2 - 3 } \cline { 5 - 6 } & $\mathrm{RC}(\%)$ & $\mathrm{BM}(\%)$ & & $\mathrm{RC}(\%)$ & $\mathrm{BM}(\%)$ \\
\hline $\begin{array}{l}\text { Fragility curves } \\
\text { Estimation }\end{array}$ & $7-8$ & 20 & 5 & 17 \\
$\begin{array}{c}\text { Sankhu } \\
\text { Real damage } \\
\text { Khokana } \\
\text { Real damage }\end{array}$ & 6 & 72 & 0 & 40 \\
\hline
\end{tabular}




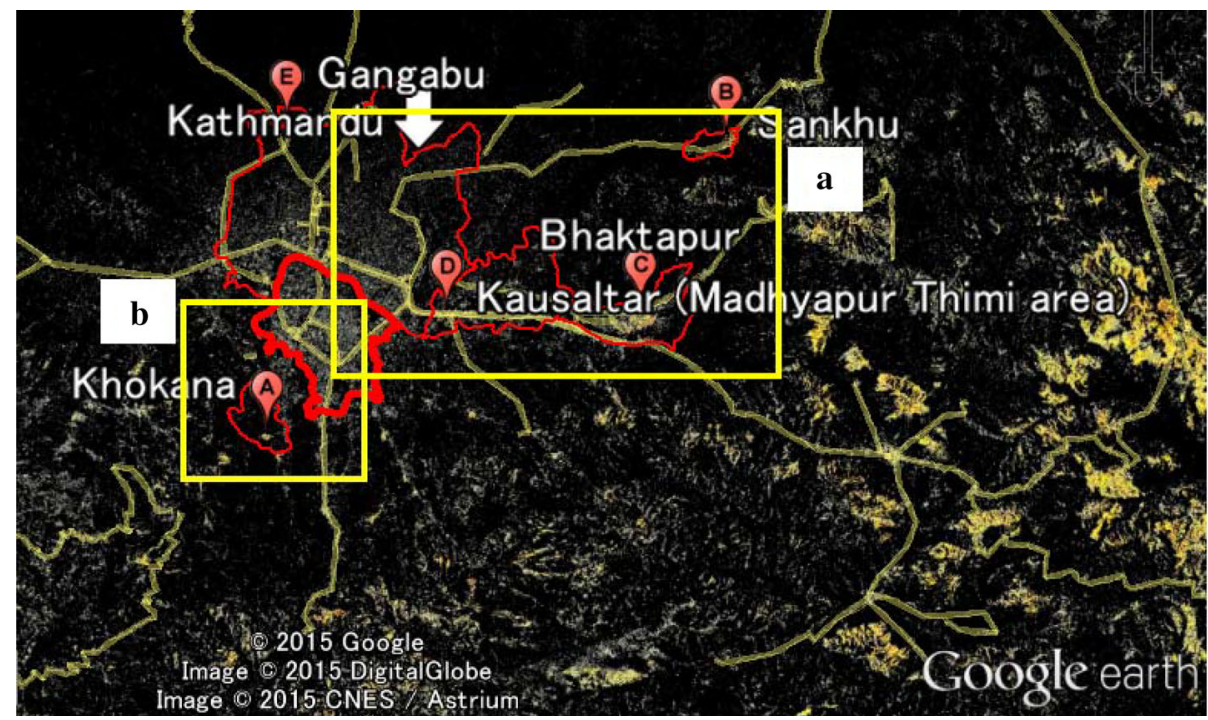

$$
\Delta \gamma=\frac{\gamma_{\text {pre2-pre1 }}-\gamma_{\text {pre2-int }}}{\gamma_{\text {pre2-pre1 }}+\gamma_{\text {pre2-int }}}
$$

Red : $\Delta \gamma \geq 0.4$

Orange : $\Delta y \geq 0.3$

Fig. 25 Full view of the area as a Google Earth image, including $\mathbf{a}$ the Timi, Bhaktapur and Sankhu core areas and $\mathbf{b}$ the Kirtipur, Khokana and Bungamati core areas. The damaged core area is detected using the coherence change $(\Delta \gamma)$ obtained before the disaster $\left(\gamma_{\text {pre }}\right)$ and between the disasters $\left(\gamma_{\text {int }}\right)$. Subscript (pre2-pre1): Two coherences that were acquired from the images before the disaster $\left(\gamma_{\text {pre }}\right)$. Subscript (pre2-int): Two coherences that were acquired from the images before the disaster $\left(\gamma_{\text {pre }}\right)$ and between the disasters $\left(\gamma_{\text {int }}\right)$
Fig. 26 Bright reflection areas for severely damaged urban area such as Timi, Bhaktapur and Sankhu core areas

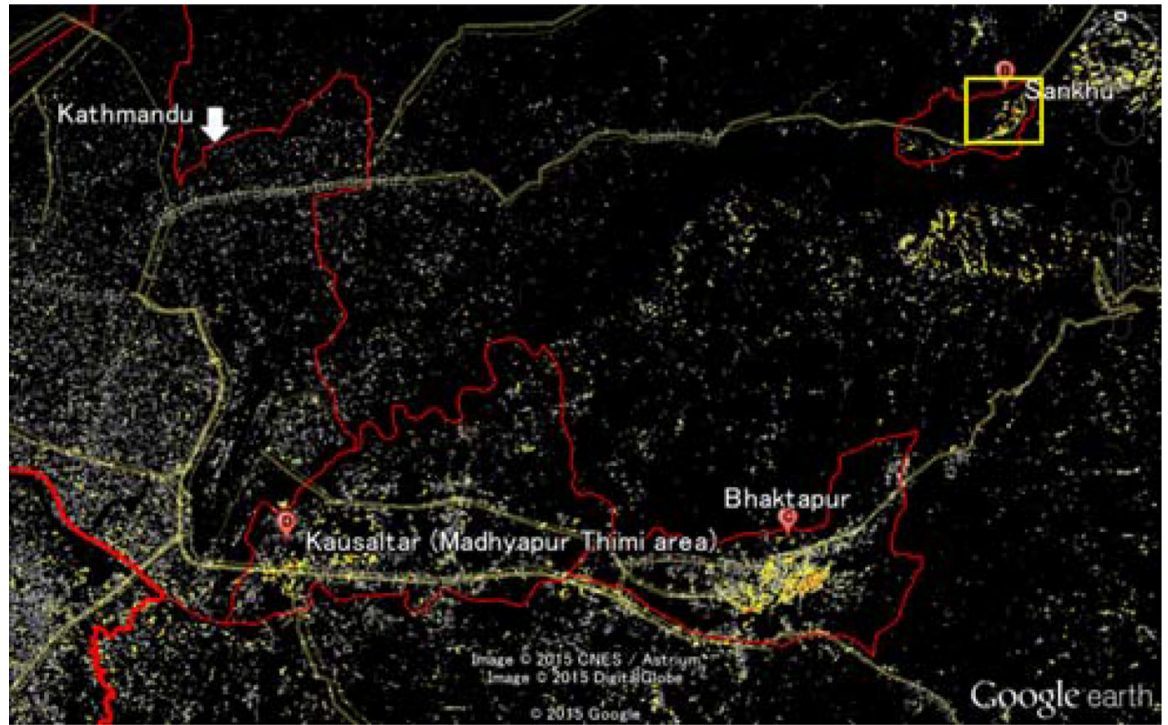

and a survey of damage extent for every house in Khokana. Reflections in the slightly damaged Kirtipur core area are not as clear and bright as those in the severely damaged core areas of Khokana and Bungamati.

\subsubsection{Reason for Slight Damage at Kirtipur}

The epicentral distance of the Kirtipur core area was $79.74 \mathrm{~km}$, compared with $80.69 \mathrm{~km}$ for the epicentral distance of the Khokana core area. Both core areas are 
Fig. 27 Coherence magnitude (a) and survey of damage extent (b) for every house in Sankhu
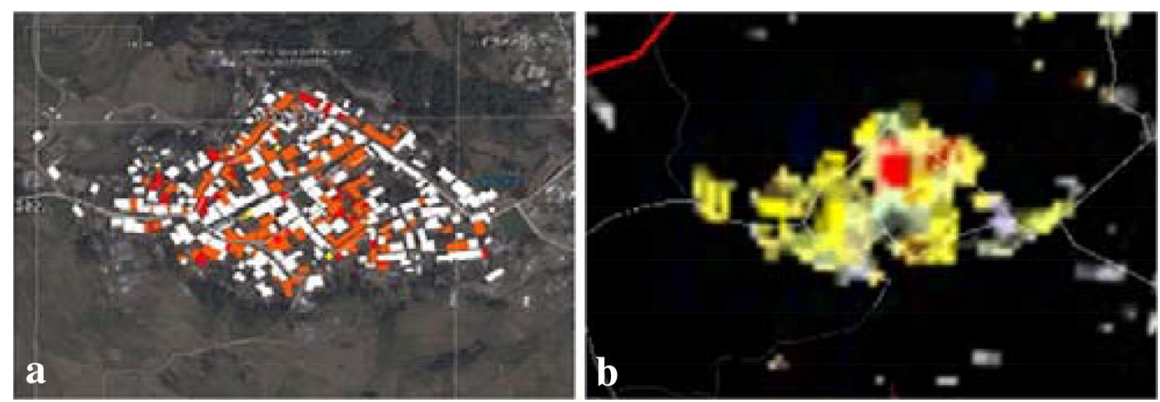

Fig. 28 Bright reflection areas for Khokana and Bungamati core areas. Kirtipur was not clear bright reflection

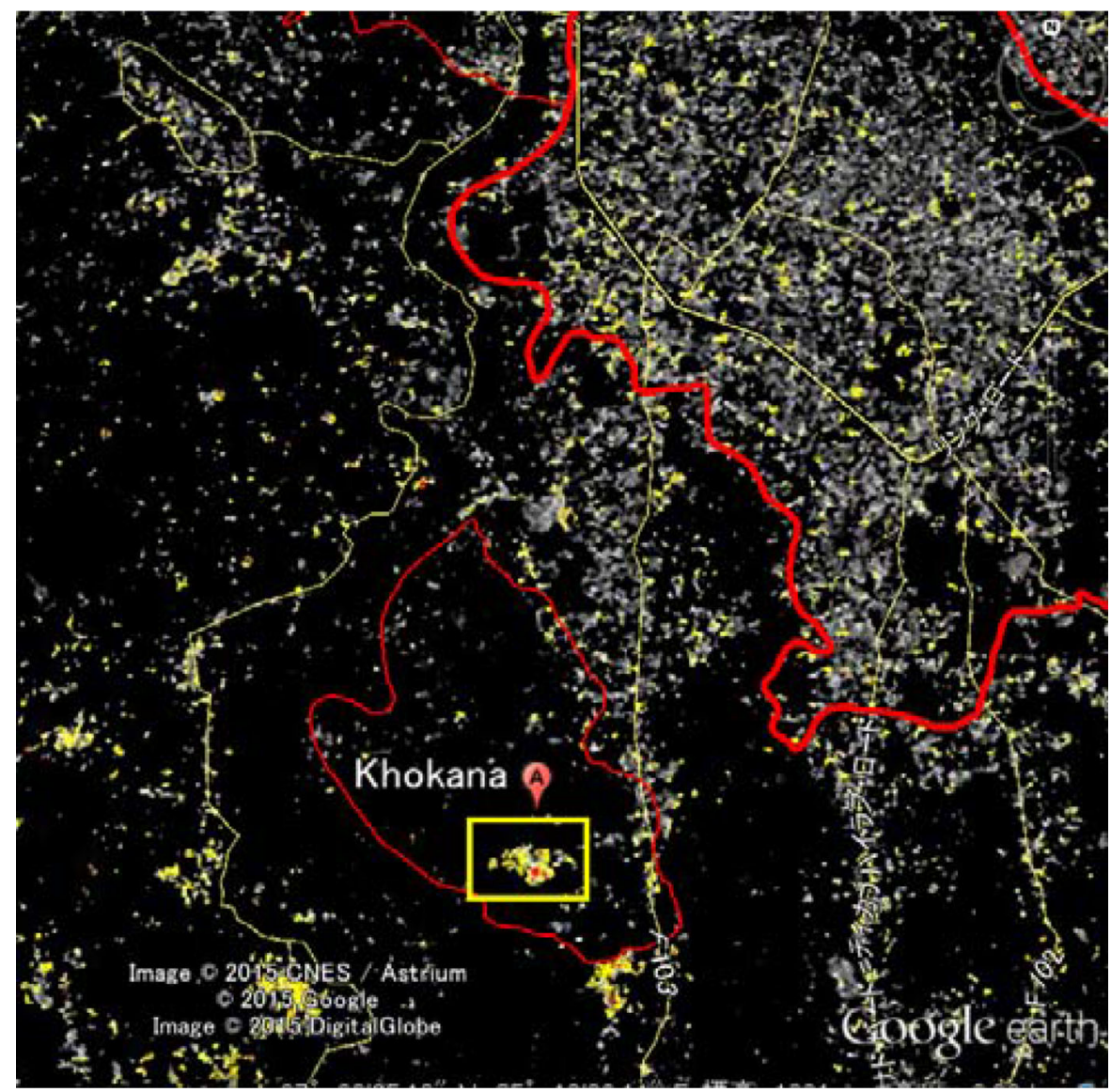

old traditional towns on small hills in the southwestern Kathmandu Valley. According to Takai et al. (2015), acceleration was amplified in Patan (Khokana) located in the Kathmandu Valley. In contrast, acceleration was less amplified in Kirtipur, which is located on outcropping basement rock units outside the valley.

\section{After the 2015 Gorkha, Nepal Earthquake and Beyound}

The recovery and reconstruction processes following the 2015 Gorkha, Nepal Earthquake are ongoing. The damage to RC structures was generally minor. Many 
Fig. 29 Coherence magnitude (a) and survey of damage extent (b) for every house in Khokana
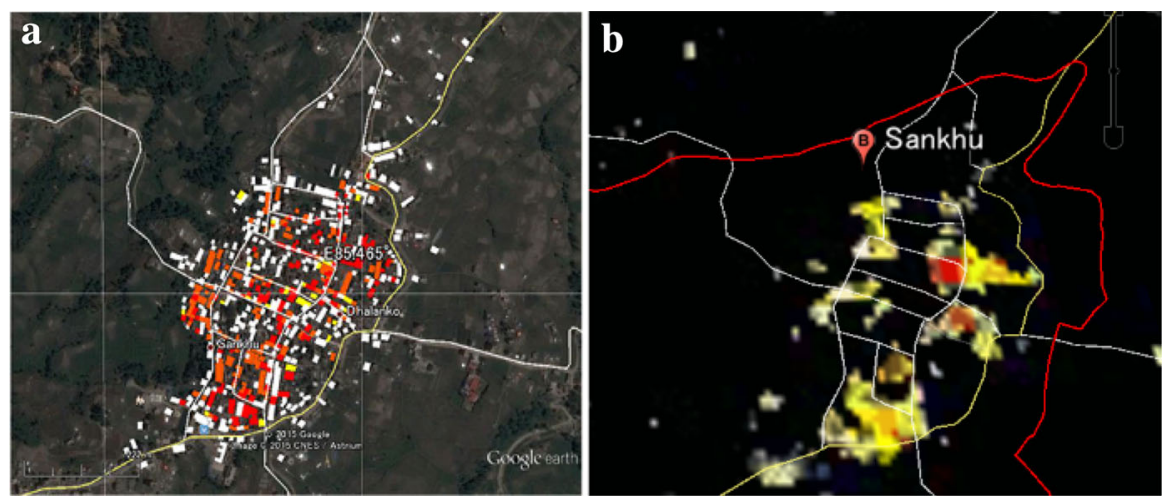

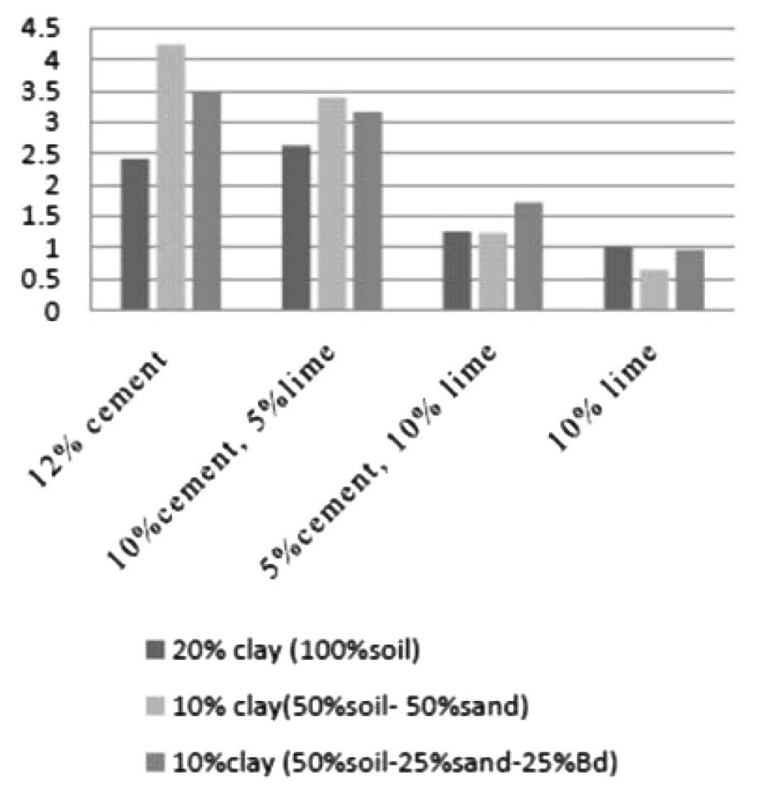

Fig. 3028 days compressive strength (Rashmi et al. 2014) $\mathrm{Y}$-axis is each magnification of the strengths of the case indicate taken as 1 at $20 \%$ clay (100\% soil) case after 28 days of curing

of the non-engineered masonry structures that experienced complete collapse or partial damage were twoto four-story buildings. Although many of the masonry structures will be reconstructed as RC structures, traditional building methods should be sustained by traditional communities not only to conserve world heritage but also to improve the earthquake resistance of cities. In the following subsections we present a method for the constructing earthquake-resistant buildings using traditional methods.

\subsection{Stabilized Mud Mortar with Lime}

In the Sankhu core area, traditional buildings over 100 years old suffered little damage in the 2015 Gorkha Earthquake. Well-built historical buildings underwent expensive improvements for earthquake resistance, which included using a mix of plaster and mud. Rashmi et al. (2014) proposed the use of a homogenous mixture comprising fine aggregates as mud mortars to bind, individually or combined with cement and lime (Fig. 30). According to this report, the workability and strength of twelve different combinations of stabilized mud mortars were examined. The compressive strength of mortar with $50 \%$ sand and $12 \%$ cement is in the range of $4.25 \mathrm{MPa}$, which is within the IS (Indian Standard) code specification. The use of this mixture as a stabilizing mud mortar in construction was shown to be sustainable as well as economical.

\subsection{Horizontal Timber Beam Reinforcement}

A number of documents discussing improvements in seismic-resistant construction methods for masonry structure were prepared under the National Building Code Development Project (NEP/88/054/21.03) in 1993.

"Guidelines for Earthquake Resistant Building Construction: Low Strength Masonry (LSM)" is one of them. This document provides basic guidelines for earthquake-resistant construction methods of lowstrength masonry. 
Fig. 31 Placement of timber for horizontal reinforcement bands (after National Building Code NBC203). Wooden Collar Beam with anchor bolt (a), Horizontal reinforcement with liner (b), Two sawn lumbers (c)
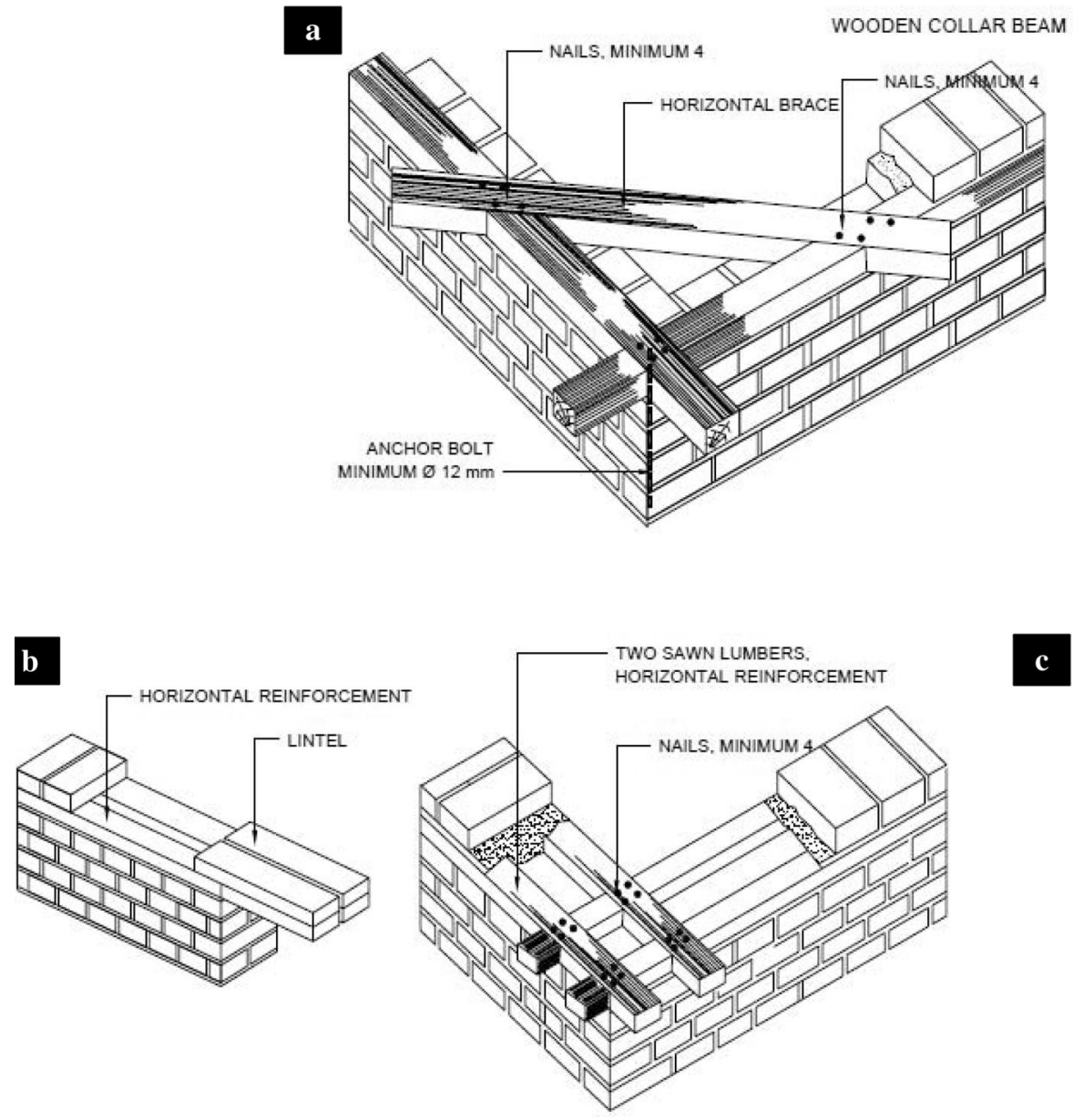
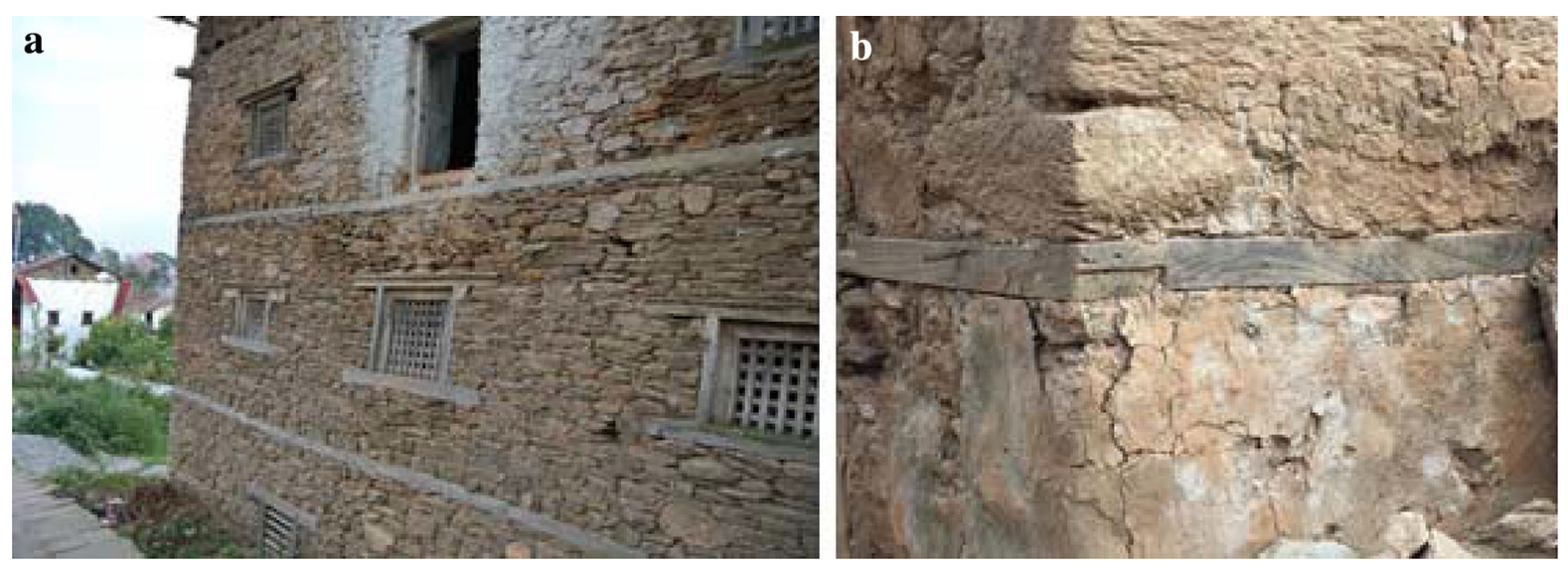

Fig. 32 Timber band installed between the first and second floors in a house in Charikot (a) and Corner joint of horizontal timber planks (b). (Photos by Dr. Hiroshi Imai of the JICA study team) 
NBC Mandatory Basic Rules for Load Bearing

202 Masonry

NBC Guidelines for Earthquake Resistant

203 Building Construction: Low Strength

Masonry

NBC Guidelines for Earthquake Resistant

204 Building Construction: Earthen Buildings (EB)

NBC 203 and 204 describe the effect of wooden strips as horizontal reinforcing members. An assemblage of two parallel lengths of timber connected by struts is placed horizontally in the wall covering the entire thickness of the wall, as illustrated in Fig. 31.

In Dolakha Bazaar, an old town located $4 \mathrm{~km}$ from Charikot in north-eastern Nepal, the buildings installed horizontal timber support planks. The timber planks were installed between the first and second floors of the building, along the outside wall of the building. In buildings with narrow sides and a gable wall, the timber is usually fitted along the outer periphery of the building separate from the floor beam. In the long side of the building, the timber is installed so as to form a common joint in the outer periphery of the building. The corner joint varies according to the building style, but notched joints are commonly used (Fig. 32).

Traditional construction methods should be sustained by traditional communities not only to conserve world heritage but also to improve the earthquake resistance of cities. Technologies for the construction of earthquake-resistant buildings using traditional methods such as stabilizing buildings using mud mortar with lime and horizontal timber beams are both effective and sustainable.

\section{Conclusions}

1. RC buildings were partially damaged, and many masonry buildings were severely damaged. The difference in damage extent between the various building types was remarkable.

2. Along the west side of the Kathmandu Ring Road, $\mathrm{RC}$ frame buildings were damaged in some cases by during the 2015 Gorkha, Nepal Earthquake.
The building damage might be caused by the soft ground conditions near the river branch as well as inappropriate construction methods.

3. BM buildings survived in urban and rural areas. These buildings have very poor horizontal rigidity because of low bond strength and strong moisture absorption in mud joints, wooden floors and roofs.

4. Damage extent and building type classification were surveyed for every house in Sankhu and Khokana. There was no damage to $94 \%$ of surveyed RC buildings. The collapse ratio was improved using $\mathrm{BC}$ relative to $\mathrm{BW}$.

5. Some buildings survived the 1934 Bihar Earthquake and the 2015 Gorkha Earthquake in Sankhu. These building structure types were classified as well built, using a type of brick with mud mortar.

6. For RC, the actual damage rate and damage function rate were in good agreement. The damage curve of BM exceeded that of ST and AD.

7. Tradition chowks are observed to have excellent earthquake resistance. However, chowks that have been altered and/or changed were damaged.

8. Comparison of the coherence magnitude with a survey of the damage extent for every house in Sankhu and Khokana detected damage well. Greatest damage correlated with the decreases of coherence $(\gamma)$ in SAR imagery observed before and after the disaster. The brightest reflections occurred for severely damaged core areas, such as those in Khokana and Bungamati. Regions of lessbright reflections, such as those observed in Kirtipur, corresponded to only slightly damaged core areas.

Acknowledgments We thank Assistant Prof. Ram Prasad Suwal of the Nepal Engineering College for permission to use the sketch of the fractures shown in Figs. 10, 17, and for providing us many comments.

Open Access This article is distributed under the terms of the Creative Commons Attribution 4.0 International License (http:// creativecommons.org/licenses/by/4.0/), which permits unrestricted use, distribution, and reproduction in any medium, provided you give appropriate credit to the original author(s) and the source, provide a link to the Creative Commons license, and indicate if changes were made. 


\section{References}

Arya A (2000) Non-engineered construction in developing countries-an approach toward earthquake risk prediction. In: Proceedings of 12th WCEE, No. 2824

Dikshit AM (1991) Geological effects and intensity distribution of the Udayapur (Nepal) earthquake of August 20, 1988. J NGS 7:1-17

Grünthal G (1998) European Macroseismic Scale 1998, in Cahiers du Centre Européen de Géodynamique et de Séismologique, vol 15. Centre Européen de Géodynamique et de Séismologie, Luxembourg, p 101

Gutschow N, Kölver B, Shresthacarya I (1987) Newar towns and buildings: an illustrated dictionary Newari-English (Nepalica), p 293

JICA (2002) The study on earthquake disaster mitigation in the Kathmandu Valley of Nepal. http://www.franceseisme.fr/ EMS98_Original_english.pdf

Murakami HO, Fujiwara TS, Kubo T (1990) Pattern of casualty occurrence due to the 1988 Earthquake in the Nepal-India Border Region, 9SEE-90. Roorkee 1(3):25-32

Ohsumi T, Imai T, Inoue H, Aoi S, Fujiwara H (2015) Investigation of damage in and around Kathmandu valley related to the 2015 Gorkha, Nepal earthquake report of the National Research Institute for Earth Science and Disaster Prevention, No. 404, March, 2015, pp 1-54

Rashmi S, Jagadish KS, Nethravathi S (2014) Stabilized mud mortar. Int J Res Eng Technol 3(Special Issue):233-239

Takai N, Sigefuji M, Bijukchhen S, Ichiyanagi M, Sasatani T (2015) Storong motion of the Gorkha Earthquake Nepal earthquake. Bull JAEE 26:2-5

Toffin G (1991) Man and his house in the Himalayas. Sterling Publishers Private Limited, New Delhi, pp 95-107 ISBN8120713648

UNDP/UNCHS (1994) The development of alternative building materials and technologies for Nepal. His Majesty's Government of Nepal Ministry of Housing and Physical Planning, UNDP/UNCHS (Habitat) SubprojectNEP/88/ 054/21.03, Appendix C-seismic vulnerability analysis, BECA, TAEC, SILT, URR

Watanabe M, Thapa RB, Ohsumi T, Yonezawa C, Tomii N, Suzuki S (2015) Detection of damaged urban area by using interferometric SAR coherence change with PALSAR-2. Earth Planets Space (submitted) 